\title{
A new species of Schendylops Cook, 1899 from a high plateau of the Córdoba mountains (central Argentina), with notes on other Neotropical members of the genus (Myriapoda: Chilopoda: Geophilomorpha)
}

\begin{abstract}
Luis A. Pereira
CONICET and Natural Sciences Faculty and Museum, National University of La Plata, Paseo del Bosque s./n., (1900) La Plata, Provincia de Buenos Aires, Argentina. E-mail: lpereira@fcnym.unlp.edu.ar

Abstract

Schendylops achalensis sp. n. (Chilopoda: Geophilomorpha: Schendylidae) is here described and illustrated from a female (holotype) and a male (paratype) from Pampa de Achala plateau, Córdoba mountains (central Argentina). The new species is characterized by having well defined pore fields on the sterna of the anterior and posterior region of the body, but totally absent on the intermediate ones, this character being shared by only four other Neotropical species of the genus, i.e., Schendylops demangei (Pereira, 1981), Schendylops demartini (Pereira \& Minelli, 1996), and Schendylops placcii (Pereira \& Minelli, 1996) from Argentina, and Schendylops minutus (Pereira \& Minelli, 1993) from Venezuela, with which it is here compared in detail. New diagnoses for these latter species are also given.
\end{abstract}

\section{Key words}

Schendylops, new species, Central Argentina, Pampa de Achala plateau, Chilopoda, Geophilomorpha, Neotropical Region

\section{Introduction}

The centipede genus Schendylops Cook, 1899 is one of the most widespread genera of the geophilomorph family Schendylidae, showing an amphiatlantic pattern of distribution (Pereira 1998; Pereira et al. 1997, 2004). Of the 63 species currently included in the genus, 51 (in addition to the new species described below) occur in the Neotropics, while seven species are known from mainland Africa and five from Madagascar. The Neotropical species are distributed as follows: one occurs in Argentina and Paraguay; 
10 in Argentina only; two in Paraguay only; two in Bolivia; 21 in Brazil; one in Colombia; two in continental Ecuador and one in the Galapagos Islands; one in Guyana; one in French Guiana; five in Peru; one in Puerto Rico and Guadeloupe; one in Venezuela, Virgin Islands and Martinique; two in Venezuela only; one in Suriname.

In the present contribution a new species of the genus is described from Argentina on the basis of specimens collected by Martin J. Ramirez and Lara Lopardo (arachnologists of the Museo Argentino de Ciencias Naturales "Bernardino Rivadavia", Buenos Aires) in Pampa de Achala, a high plateau of the Córdoba mountains (central part of the country). Until present, the genus was known from seven Argentinian provinces, with 11 species distributed as follows: one in Buenos Aires and Chaco provinces, two in Buenos Aires province only, one in Misiones and Entre Rios provinces, two in Entre Rios province only, three in Misiones province only, one in Formosa province, and one in Chubut province. Schendylops achalensis sp. $\mathrm{n}$. is the twelfth species of the genus to be known for the Argentinian fauna and the first record of the taxon for Córdoba province, thus extending the range of the genus to the central region of the country.

Schendylops achalensis sp. $\mathrm{n}$. is characterized by the presence of well defined pore fields on the anterior and posterior sterna, but totally absent on the intermediate ones, this character being shared by four other Neotropical species of the genus, i.e., Schendylops demangei (Pereira, 1981), Schendylops demartini (Pereira \& Minelli, 1996), and Schendylops placcii (Pereira \& Minelli, 1996) from Argentina, and Schendylops minutus (Pereira \& Minelli, 1993) from Venezuela, with which the new species is compared in detail. The opportunity to reexamine type specimens of these last species allowed the addition of further morphological data and new illustrations which complement previous treatments on these taxa. The latest contributions to the knowledge of the Neotropical species of Schendylops can be found in Demange \& Pereira $(1979,1985)$, Pereira $(1981,1983$ a, b, c, 1984, 1985 a, b, 1999), Pereira et al. (1994, 1995, 2002) and Pereira \& Minelli $(1993,1996)$. The species from mainland Africa have been revised by Pereira \& Minelli (1994, 2001) and those from Madagascar by Hoffman \& Pereira (1997) and Pereira et al. (2004).

\section{Materials and methods}

The holotype and paratype herein designated are deposited at the Museo Argentino de Ciencias Naturales "Bernardino Rivadavia", Buenos Aires (MACN); other type material revised here is currently housed at the Museo de La Plata (MLP) and Museo Civico di Storia Naturale di Verona (MSNVR) as indicated under each species. All specimens were examined through a light microscope equipped with a drawing tube attachment which was used to delineate the figures and taking measurements in $\mathrm{mm}$ (from a micrometer objective). Details on employed dissection procedures are described in Pereira (2000) and Foddai et al. (2002). Only temporary mounts have been prepared by direct transfer of the specimens from the preservation liquid (70 per cent ethanol) onto microscopic slides, using as a mounting medium undiluted ethylene glycol monophenyl ether (= 2-Phenoxyethanol) (CAS No. 122-99-6). No additional steps were employed 
before mounting. The slides were stored in hermetic acrylic boxes to avoid evaporation of the fluid. The digitalized figures were prepared by arranging the original drawings in plates which were scanned at a resolution of $600 \mathrm{dpi}$, in black and white ("line art") mode, storing the files in tiff format. Later, using Photoshop, each file was edited and saved in the same format with LZW compression.

The following abbreviation was used in the text and legends of the figures: a.a., antennal article.

\section{Results}

\section{Family Schendylidae Genus Schendylops Cook, 1899}

Diagnosis: This taxon can be recognized by the following unique combination of characters: Pleurites of second maxillae not fused to coxosternum. Apical claw of telopodite of second maxillae pectinate on both dorsal and ventral edges. Sterna with pore fields. Last pair of legs with seven podomeres; pretarsus in form of a small hirsute tubercle or replaced by a small spine or altogether absent. Coxopleura of last leg-bearing segment each with two internal coxal organs of simple structure ("homogeneous coxal glands" sensu Brölemann \& Ribaut, 1912).

Type of the genus: Schendyla grandidieri Saussure \& Zehnter, 1897, by original designation.

Remarks: For a detailed list of the species of Schendylops from the Neotropics and mainland Africa, see Minelli (2006).

\section{Schendylops achalensis sp. $\mathrm{n}$.}

Figs 1-53.

Diagnosis: A Schendylops species with well defined pore fields on the sterna of the anterior and posterior region of the body, but totally absent on the intermediate ones. Of the other Neotropical species included in the genus, only the present new species, $S$. demangei (Pereira, 1981), S. demartini (Pereira \& Minelli, 1996), S. minutus (Pereira \& Minelli, 1993), and S. placcii (Pereira \& Minelli, 1996) share this trait. S. achalensis sp. $\mathrm{n}$. is differentiated from these last by the following unique traits: clypeus with 22 setae on the middle; sternum of last leg-bearing segment relatively wide, with width/length ratio 1.97: 1 in the male and 2.14: 1 in the female.

Remark: Morphological characters in Table 3 differentiate S. achalensis sp. n. from S. demangei, S. demartini, S. minutus and S. placcii.

Type material examined: Holotype: female, 47 leg-bearing segments, body length $27 \mathrm{~mm}$; Paratype: male, 43 leg-bearing segments, body length $22 \mathrm{~mm}$ from Argentina: Córdoba province: Punilla department: Pampa de Achala, $15 \mathrm{~km}$ W of El Condor, 31 
July 1999, M. J. Ramirez and L. Lopardo leg. In acohol. Depository of types: MACN. (MACN-My 1: Holotype female; MACN-My 2: Paratype male).

Remarks. The adult condition of both specimens is proved by the presence of spermatozoa in the spermathecae of the female and mature spermatozoa in the tubula seminifera of the male.

Description (Female Holotype): Forty-seven leg-bearing segments, body length 27 $\mathrm{mm}$, maximum body width $1.0 \mathrm{~mm}$, length of cephalic plate $0.61 \mathrm{~mm}$, width of forcipular coxosternum $0.63 \mathrm{~mm}$. Color (of preserved specimen in alcohol): head, forcipular segment and leg-bearing segments I-X (-XI) bright ocher, rest of the body yellowish. Terga, pleurae and sterna of leg-bearing segments I-XII (-XIII) with surface sharply reticulated (as shown in Fig. 24: a).

Antennae: relatively short, ca. 2.3 times as long as the cephalic plate, distally slightly attenuate; first article wider than long, second article as long as wide, articles III-XIV longer than wide. Setae on a.a. I-IV (-V) of different length, few in number, those of remaining articles progressively shorter and more numerous towards the tip of the appendage (Fig. 1). Terminal a.a. with $c a$. 11-13 claviform sensory setae on the external border and one on the internal border (Fig. 2). Distal end of this a.a. with $c$ a. five very small, equally trifid specialized sensilla (Fig. 2). Ventral and dorsal surface of a.a. II, V, IX and XIII (Figs 3, 4) with very small specialized sensilla. Ventral sensilla of two types ( $a$ and $b$ ). Type $a$ sensilla very thin and not split apically, type $b$ sensilla very similar to those of the apex of the terminal a.a. (Fig. 3: a, b). Position of type $a$ and $b$ sensilla varies from antero-median on a.a. II and IX, to internal apical-lateral on a.a. IX and XIII. Specialized sensilla on dorsal side represented by three different types: $a$ and $b$ similar to $a$ and $b$ of the ventral side and type $c$ sensilla similar in size to type $b$ but unequally trifid and much darker (ochreous in color) (Fig. 4: a, b, c). Position of type $a$ sensilla varies from antero-median on a.a. II to apicalmedian in a.a. XIII, whereas type $b$ and $c$ sensilla always occur on the external apical-lateral region of the specified a.a. Distribution of type $a, b$ and $c$ sensilla as in Table 1.

Cephalic plate: slightly longer than wide (ratio 1.16: 1), shape and chaetotaxy as in Fig. 5.

Clypeus: with $1+1$ postantennal setae, $11+11$ median setae and $1+1$ praelabral setae (Fig. 6).

Labrum: with 20 teeth, those of the central arc robust, dark and round-tipped, the lateral ones less sclerotized, each with a relatively long, very sharp medial extension (Fig. 7).

Table 1. Number of type $a, b$ and $c$ sensilla on antennal articles II, V, IX and XIII in the female holotype of Schendylops achalensis sp. n. from Argentina: Córdoba province: Punilla department: Pampa de Achala, $15 \mathrm{~km}$ W of El Condor.

\begin{tabular}{|c|c|c|c|c|c|c|}
\hline & \multicolumn{2}{|c|}{ Ventral } & \multicolumn{3}{|c|}{ Dorsal } & \multirow{2}{*}{ Figs } \\
\hline & $a$ & $b$ & $a$ & $b$ & $c$ & \\
\hline II & - & - & 1 & 1 & - & \\
\hline $\mathrm{V}$ & 1 & 2 & 1 & 2 & 1 & \\
\hline IX & 1 & $2-3$ & 1 & 3 & $1-2$ & \\
\hline XIII & 1 & $1-3$ & 1 & 3 & 2 & $2-4$ \\
\hline
\end{tabular}


Mandible: dentate lamella subdivided into two distinct blocks, with 3, 8 teeth in the left mandible (Fig. 8) and 4, 6 in the right mandible; pectinate lamella with $c a .14$ hyaline teeth.

First maxillae: with large lappets on both coxosternum and telopodites (Fig. 9). Coxosternum with $2+2$ setae, median projections of coxosternum with $2+1$ setae. Article II of telopodite with $3+3$ ventral setae and $4+3$ dorsal sensilla (Figs 9, 10).

Second maxillae (Figs 10-12): with $10+12$ setae on coxosternum, arranged as in Fig. 10. Apical claw of telopodite bipectinate, dorsal and ventral edge (Fig. 12) with $c a .13$ teeth.

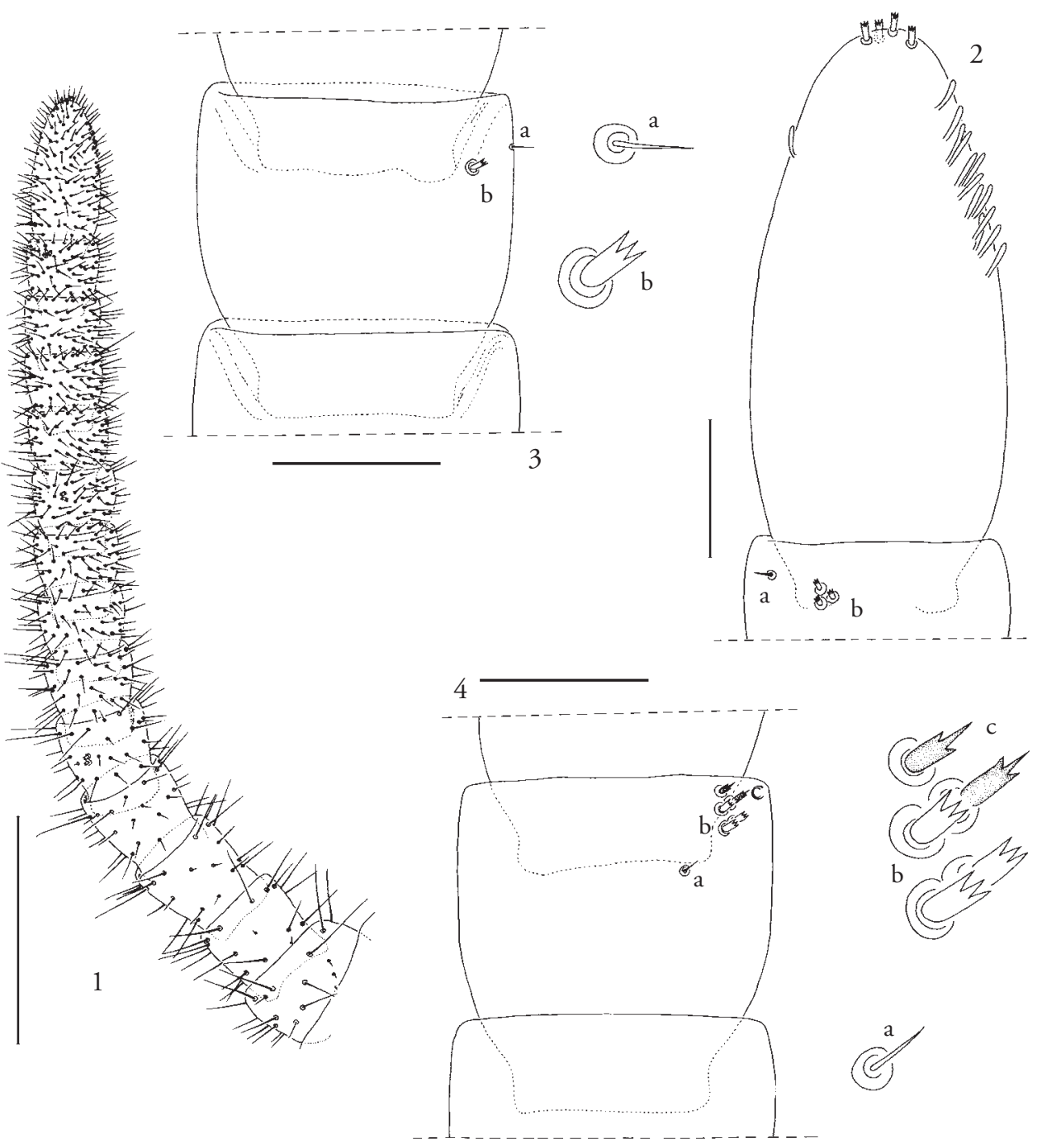

Figures 1-4. Schendylops achalensis sp. n. (q holotype; Argentina: Córdoba province: Punilla department: Pampa de Achala). (1) Left antenna, ventral. (2) Distal part of left a.a. XIII followed by a.a. XIV, ventral (a, b: $a, b$ type sensilla). (3) Right a.a. XIII, ventral (a, b: $a, b$ type sensilla). (4) Right a.a. XIII, dorsal (a, b, c: $a, b, c$ type sensilla). Scale bars: $0.3 \mathrm{~mm}(1) ; 0.05 \mathrm{~mm}(2-4)$. 
Forcipular segment: tergum trapeziform with an irregular transverse median row of $c a$. 9 large setae and a few additional smaller setae on the remaining surface (Fig. 14). All articles of telopodites without teeth. Relative size of poison gland as in Fig. 15, calyx cylindrical, relatively short (Figs 15, 16). Chaetotaxy of coxosternum and telopodites as in Figs 13, 14.

Walking legs: with chaetotaxy (Figs 17-19) uniform throughout the body length. Claws ventrobasally with two parungues, one anterior one posterior; a third smaller parun-

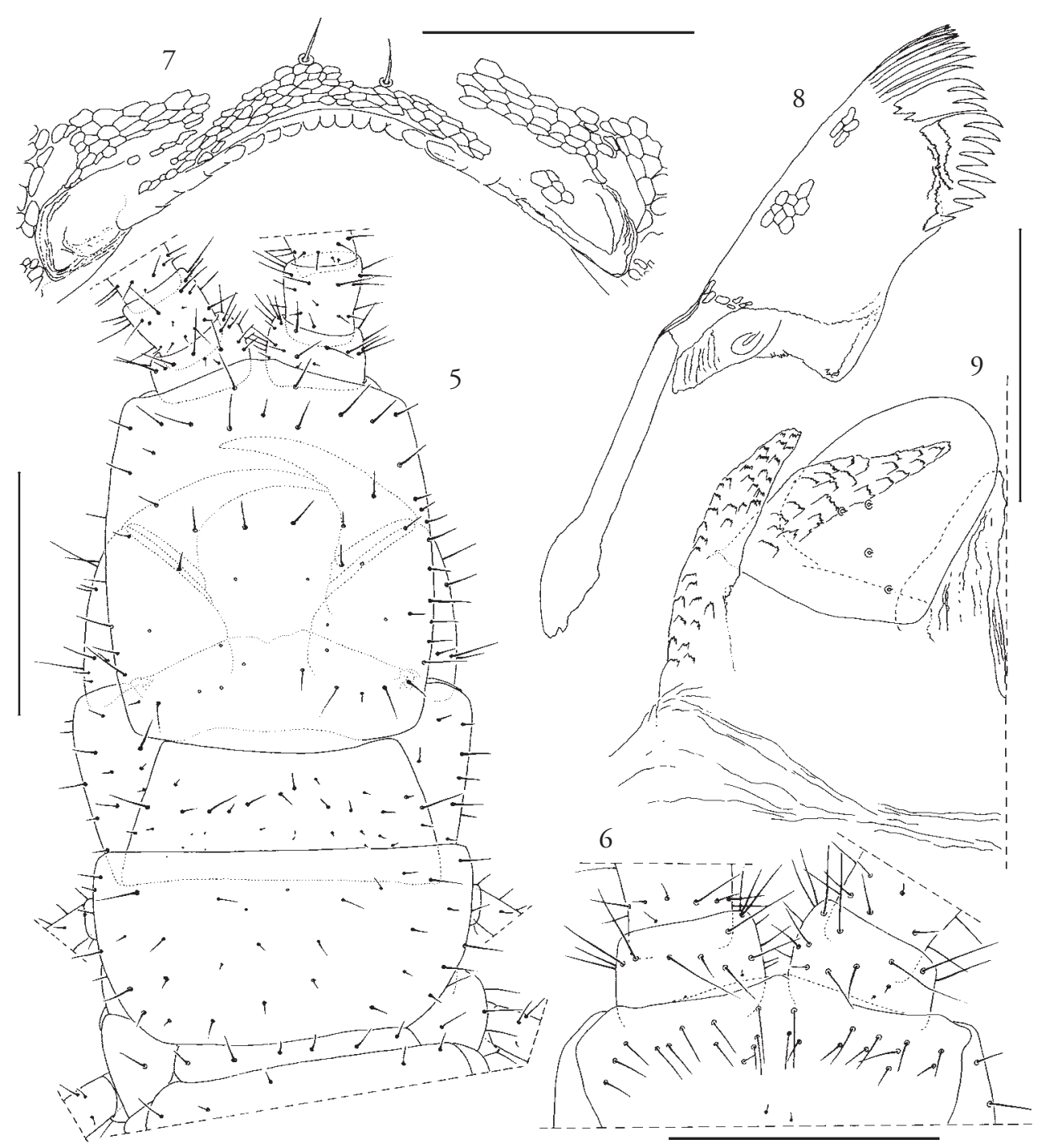

Figures 5-9. Schendylops achalensis sp. $\mathrm{n}$. († holotype; Argentina: Córdoba province: Punilla department: Pampa de Achala). (5) Dorsal view of anterior region of the body showing cephalic shield, base of antennae, forcipular segment, leg-bearing segment I, and anterior region of leg-bearing segment II. (6) Clypeus and base of antennae. (7) Labrum. (8) Left mandible, dorsal. (9) Left first maxilla, dorsal. Scale bars: 0.4 $\mathrm{mm}$ (5); $0.3 \mathrm{~mm}(6) ; 0.1 \mathrm{~mm}(7-9)$. 
guis occurs internally, very close to the posterior one. Parungues of legs I to $c a$. X (-XII) with relative size as in Fig. 20, size of parungues in the remaining legs, as in Fig. 21.

Sterna: pore fields present on sterna II-XXVII; XXIX-XXXI and XLI-XLVI (penultimate); totally absent on sterna XXVIII and XXXII-XL. Sterna II-XIV and XLV-XLVI with a main central undivided pore field area (Figs 22-26, 35, 36); sterna XV-XXIV and XLII-XLIV with pore fields subdivided in two subsymmetrical areas (Figs 27-29, 33,
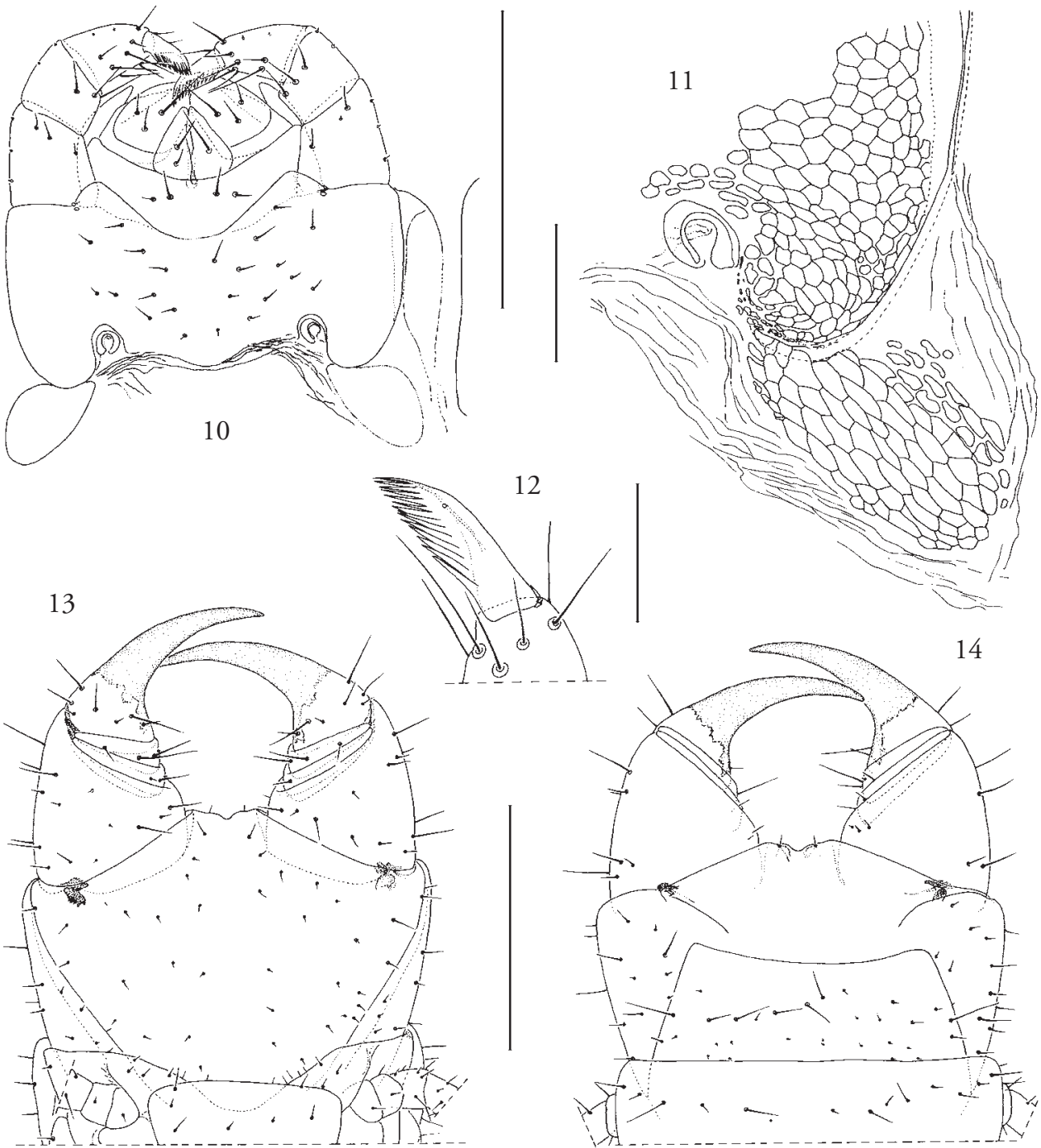

Figures 10-14. Schendylops achalensis sp. n. (우 holotype; Argentina: Córdoba province: Punilla department: Pampa de Achala). (10) First and second maxillae, ventral (11) Detail of postero-external region of left second maxilla, ventral. (12) Claw of telopodite of left second maxilla, ventral. (13) Forcipular segment and anterior part of leg-bearing segment II, ventral. (14) Forcipular segment and anterior part of leg-bearing segment II, dorsal. Scale bars: $0.3 \mathrm{~mm}(10) ; 0.05 \mathrm{~mm}(11,12) ; 0.4 \mathrm{~mm}(13,14)$. 
34); sternum XXV (Fig. 30) with pores on the right side only; sterna XXVI, XXVII, XXIX-XXXI (Fig. 31) and XLI (Fig. 32) with pores on the left side only. Undivided pore fields (except on sternum XLVI) with $c a$. one to eight additional pores on each side of
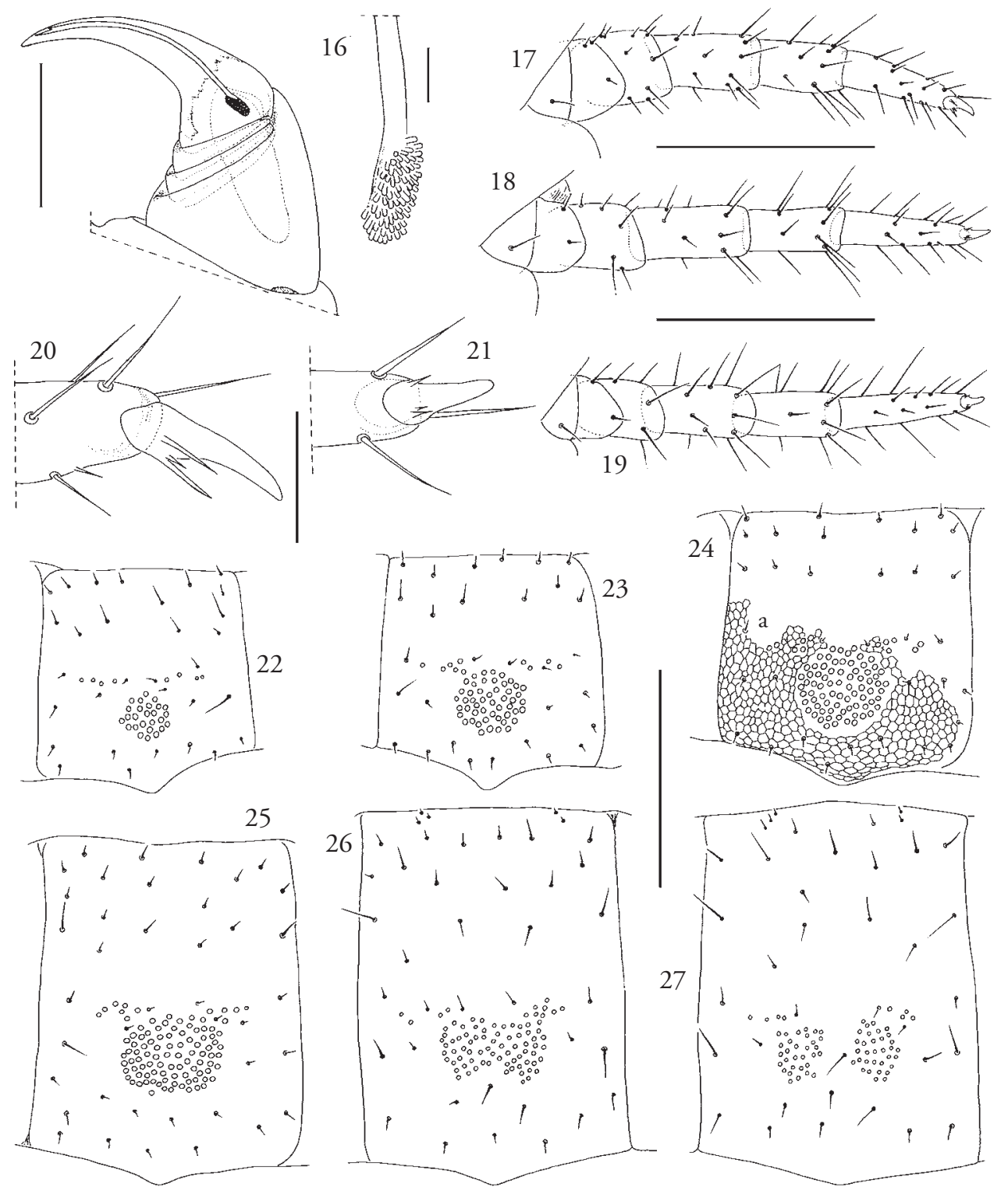

Figures 15-27. Schendylops achalensis sp. n. († holotype; Argentina: Córdoba province: Punilla department: Pampa de Achala). (15) Detail of poison gland in left forcipular telopodite, ventral. (16) Detail of calyx of right poison gland, ventral. (17) Left leg VIII, ventral. (18) Left leg XIV, ventral. (19) Left leg XLVI, ventral. (20) Claw of left leg X, antero-ventral view. (21) Claw of left leg XXXVIII, ventral. (22) Sternum II. (23) Sternum III. (24) Sternum VII (a: detail of distinct reticulation of body surface). (25) Sternum XII. (26) Sternum XIV. (27) Sternum XV. Scale bars: $0.2 \mathrm{~mm}$ (15); $0.02 \mathrm{~mm}$ (16); $0.3 \mathrm{~mm}$ (17-19); $0.05 \mathrm{~mm}$ (20, 21); $0.3 \mathrm{~mm}$ (22-27). 
the anterior border; divided pore fields either accompanied by $c a$. one to four additional pores on the external side of the anterior border, or without those pores. Shape of fields changes along the trunk as in Figs 22-36. Number of pores on selected sterna: sternum II $(4+26+4) ; \mathrm{III}(6+50+4)$; VII (6+75+6); XII (7+87+5); XIV (4+72+7); XV (4+31+33+4);
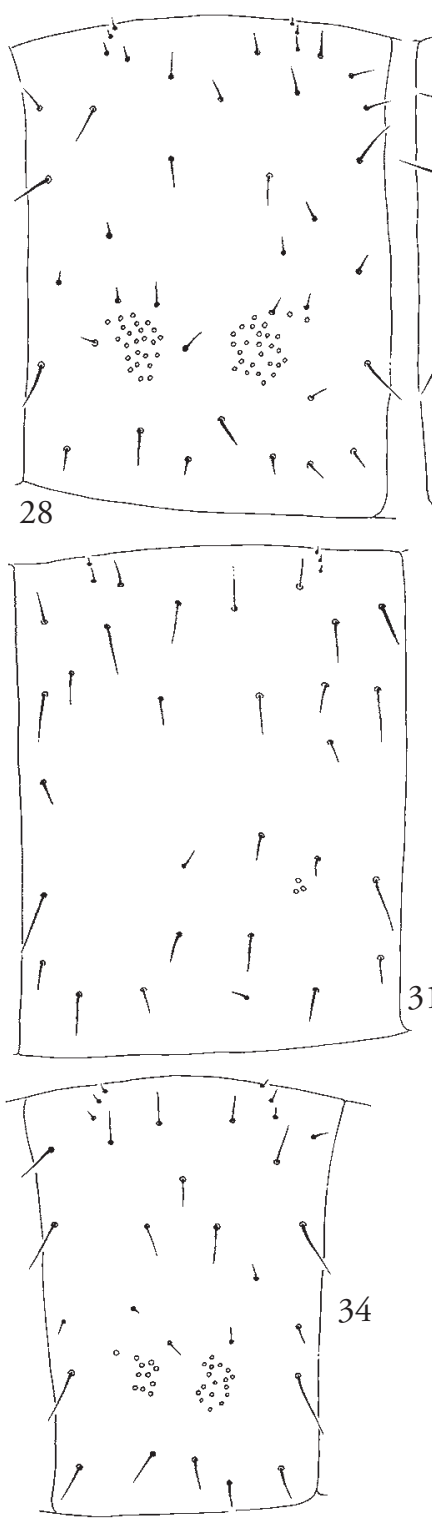
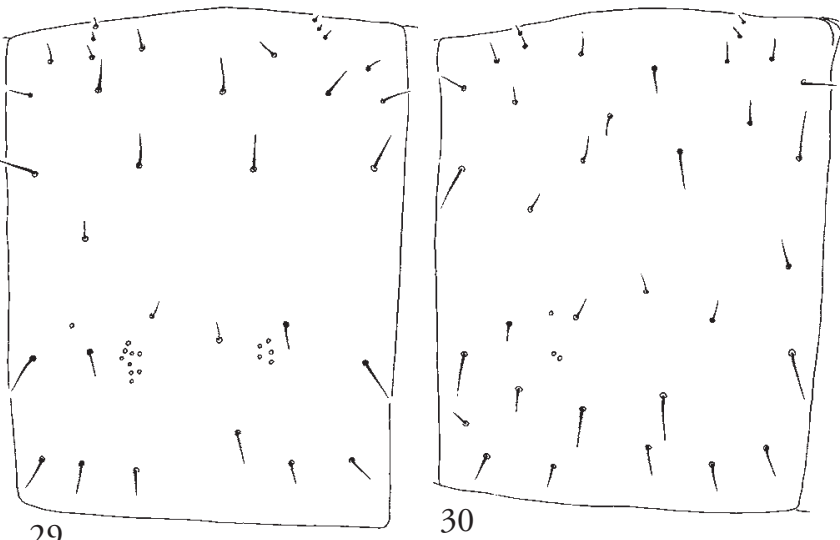

29
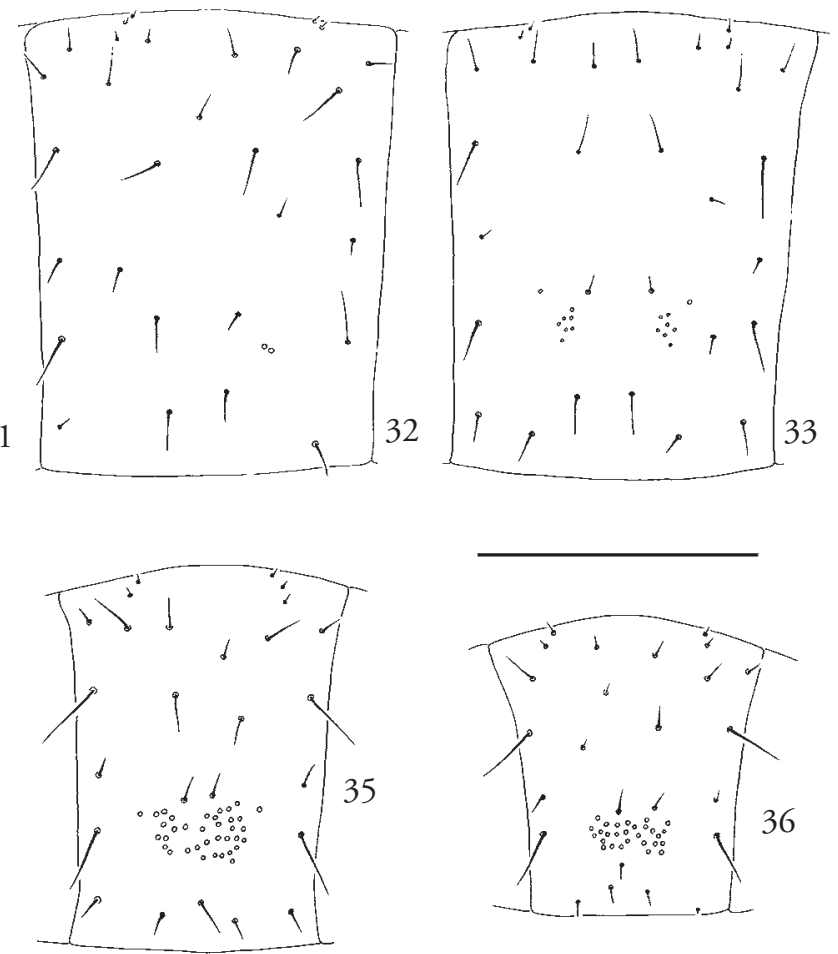

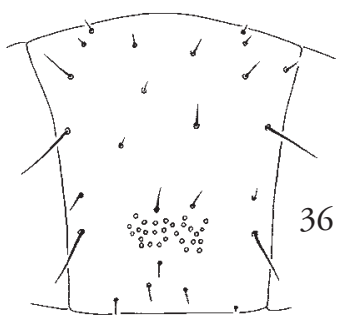

Figures 28-36. Schendylops achalensis sp. n. († holotype; Argentina: Córdoba province: Punilla department: Pampa de Achala). (28) Sternum XVIII. (29) Sternum XXIV. (30) Sternum XXV. (31) Sternum XXXI. (32) Sternum XLI. (33) Sternum XLII. (34) Sternum XLIV. (35) Sternum XLV. (36) Sternum XLVI. Scale bar: $0.3 \mathrm{~mm}$. 
XVIII $(0+24+25+2)$; XXIV $(1+9+5+0)$; XXV $(1+2+0+0)$; XXXI $(0+0+3+0)$; XLI $(0+0+2+0)$; XLII $(1+7+7+1)$; XLIV $(1+10+17+0)$; XLV $(1+34+1)$; XLVI (28).

Last leg-bearing segment: without pleurites at the sides of praetergum; praesternum not divided along the sagittal plane; sternum with middle part of posterior edge slightly notched dorsally. Shape and chaetotaxy of tergum and sternum as in Figs 37, 38. Coxopleura slightly protruding at their distal internal ventral ends, setae small and numerous on the distal-internal ventral area, the remaining surface with setae bigger and less numerous. Two single ("homogeneous") coxal organs in each coxopleuron (Figs 38, 39).

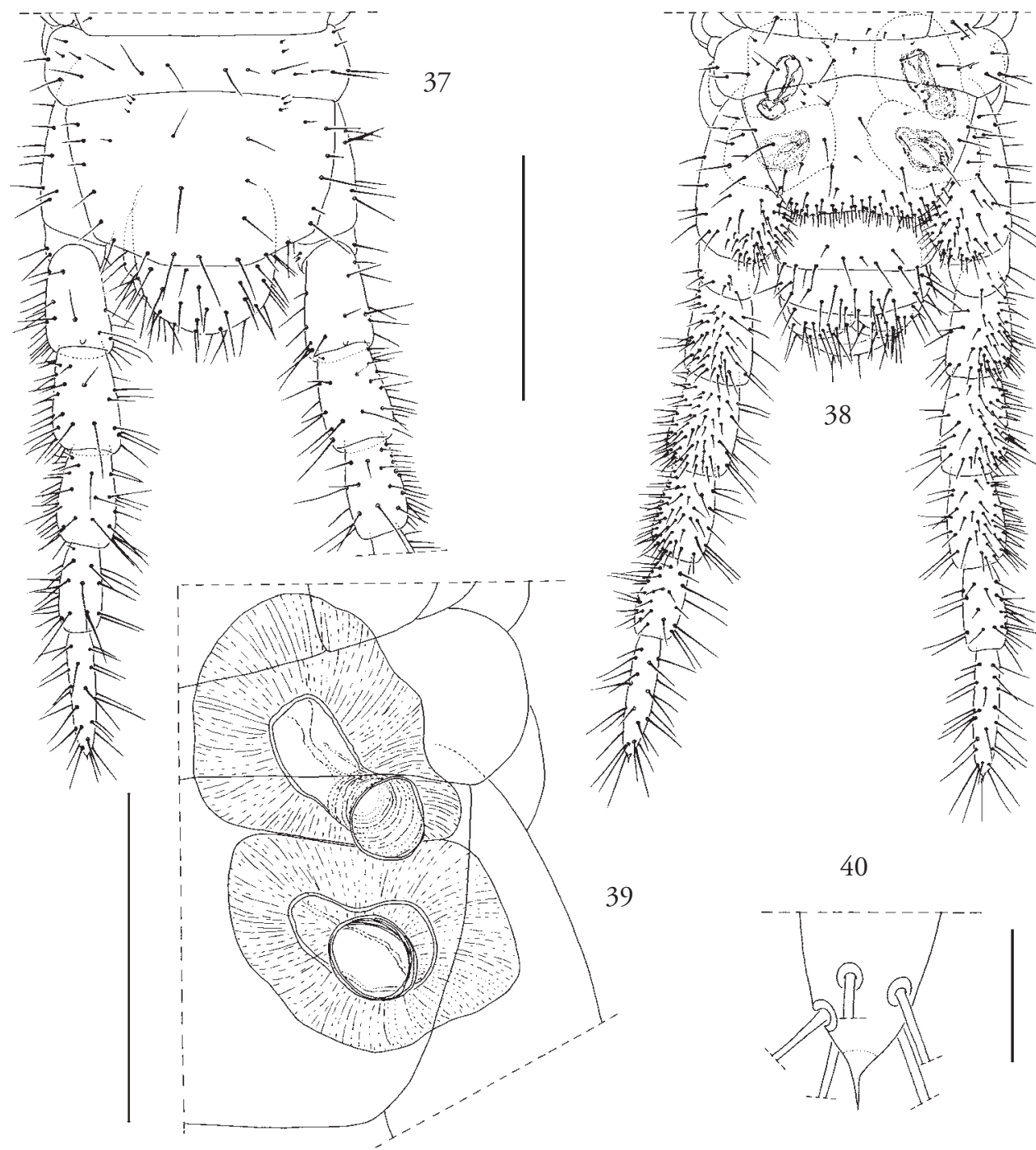

Figures 37-40. Schendylops achalensis sp. $\mathrm{n}$. († holotype; Argentina: Córdoba province: Punilla department: Pampa de Achala). (37) Last leg-bearing segment and terminal segments, dorsal. (38) Last legbearing segment and terminal segments, ventral. (39) Left coxal organs, ventral. (40) Detail of distal end of last podomere of left last leg, ventral. Scale bars: $0.4 \mathrm{~mm}(37,38) ; 0.2 \mathrm{~mm}$ (39); $0.03 \mathrm{~mm}(40)$. 
Coxal organs opening on the membrane between coxopleuron and sternum, covered by the latter. Last legs with seven podomeres, shape and chaetotaxy as in Figs 37, 38. Pretarsus as a diminutive tubercle with one very small apical spine (Fig. 40).

Terminal segments: posterior margin of intermediate tergum strongly convex, intermediate sternum with posterior border straight to very slightly concave, posterior

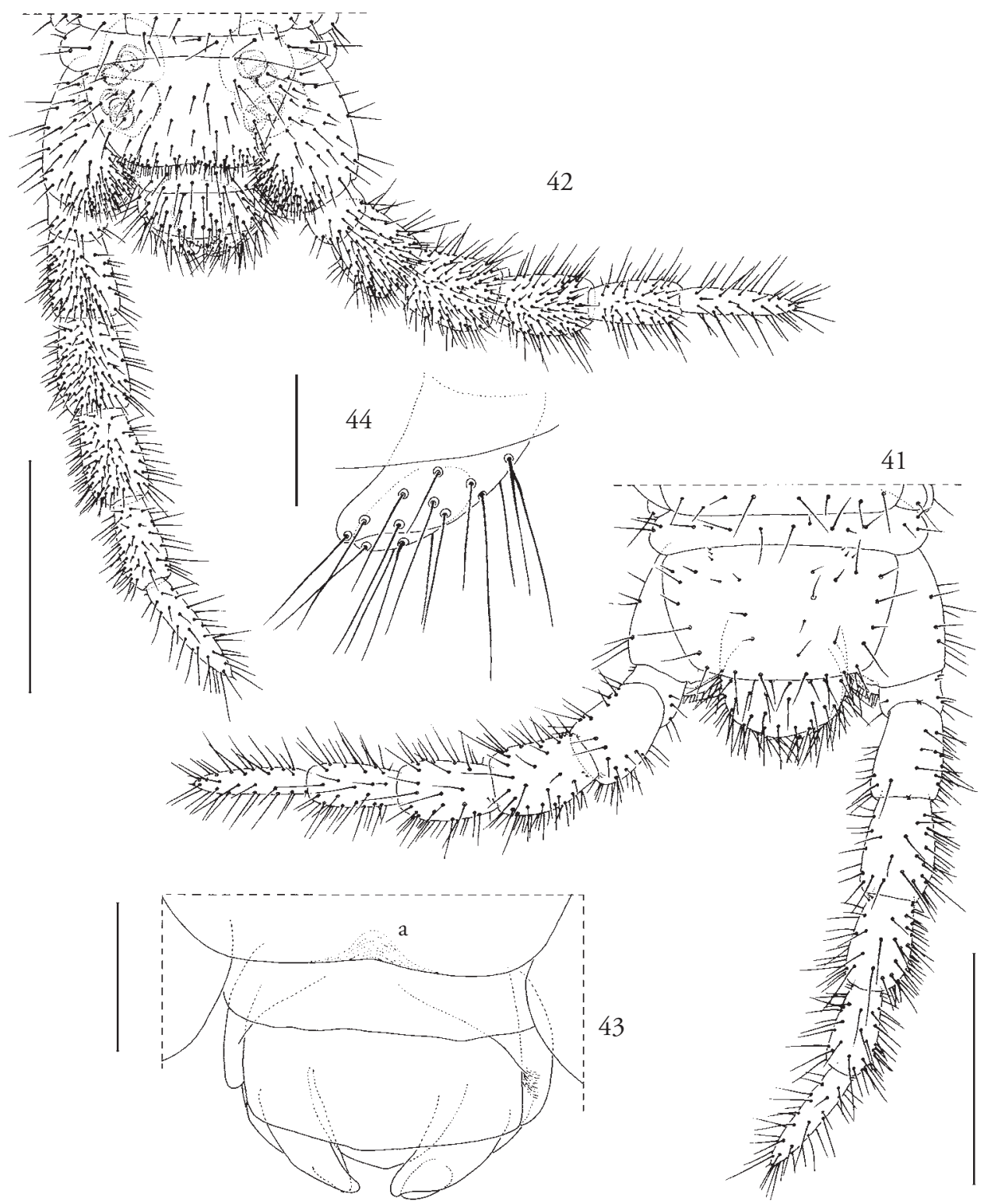

Figures 41-44. Schendylops achalensis sp. n. (ô paratype; Argentina: Córdoba province: Punilla department: Pampa de Achala). (41) Last leg-bearing segment and terminal segments, dorsal. (42) Last legbearing segment and terminal segments, ventral. (43) Terminal segments, ventral (a: small dorsal notch). (44) Left gonopod, ventral. Scale bars: $0.4 \mathrm{~mm}$ (41, 42); $0.1 \mathrm{~mm}$ (43); $0.05 \mathrm{~mm}(44)$. 
border of first genital sternum convex (Figs 37, 38). Gonopods uniarticulate, well separated on the sagittal plane with form and chaetotaxy as in Fig. 38.

Male (Paratype): Forty three leg-bearing segments, body length $22 \mathrm{~mm}$, maximum body width $0.9 \mathrm{~mm}$.

Pore fields: present on sterna II-XXIV and XXXVIII-XLII (penultimate), totally absent on sterna XXV-XXXVII. Sterna II-XII and XLI-XLII with a main central undivided pore field area; sterna XIII-XXIV and XXXVIII-XL with pore fields subdivided in two subsymmetrical areas.

All other features similar to those in the female except for the shape and chaetotaxy of the last leg-bearing segment and terminal segments.

Last leg-bearing segment: form and chaetotaxy of tergum and sternum as in Figs 41, 42. Coxopleura slightly protruding at their distal internal ventral area, which is covered by numerous small setae, remaining coxopleural surface with bigger and less numerous setae (Figs 41, 42). Most podomeres of terminal legs (apical excepted) moderately inflated, ratio width of tarsus/width of metatarsus 1.75:1, shape and chaetotaxy as in Figs 41, 42.

Terminal segments: intermediate tergum with posterior border convex, intermediate sternum with posterior border slightly concave on the middle and slightly convex at the sides, sternum of first genital segment with posterior border convex (Figs 41-43). Gonopods biarticulate, basal article with $c a .12$ setae, apical article with $c a .4$ setae (Fig. 44), apical article articulated dorso-apically with the basal one (articulation not visible from ventral side, Figs 43, 44); penis dorsally with $3+3$ apical setae (Fig. 45).

Etymology: The species is named after the type locality, Pampa de Achala.

Ecology: Pampa de Achala is a high plateau located in the Sierras Grandes, Córdoba province, central Argentina (at an altitude of 2000-2250 m a.s.l.). The climate of this area is characterized by cold, dry winters and cool, wet summers. The landscape consists of a mosaic of granite outcrops, tussock grasslands (Deyeuxia hieronymi), pasture (Alchemilla pinnata, Mulhembergia peruviana, Selaginella peruviana) and woodlands (Polylepis australis) (Jofré et al. 2007). The area hosts some endemic species, e.g. the bothriurid scorpion Urophonius achalensis Abalos \& Horminal, 1974, the carabid beetle Barypus comechingoensis (Roig Juñent, 1992) and the tenebrionid beetle Scotobius granosus Lacordaire, 1830 (Roig Juñent et al. 2003; Roig Juñent \& Debandi 2004).

\section{Schendylops demangei (Pereira, 1981)}

Figs 46-51.

Schendylurus demagei (sic) Pereira, 1981 - Rev. Soc. Entomol. Argent. 40 (1-4): 115.

Schendylurus demangei Pereira, 1981 - Rev. Soc. Entomol. Argent. 40 (1-4): 121, 122.

Schendylurus demangei: Pereira \& Minelli 1993 - Trop. Zool., Special Issue 1: 106, 108, 121.

Schendylurus demangei: Pereira \& Minelli 1996 - Trop. Zool. 9: 239, 240, 292.

Schendylops demangei: Hoffman \& Pereira 1997 - Myriapodologica 5 (2): 21.

Schendylops demangei: Morrone \& Pereira 1999 - Rev. Soc. Entomol. Argent. 58 (3-4): 167, 170.

Schendylops demangei: Foddai, Pereira \& Minelli 2000 - Amazoniana 16 :136. 
Diagnosis: The species differs from $S$. achalensis sp. n., S. demartini, S. minutus, and S. placcii by the following unique traits (cf. Table 3): female with 65 leg-bearing segments; anterior margin of sterna III-XIII provided medially with a very small shallow pit, accompanied internally by a chitinous thickening (Figs 47-49).
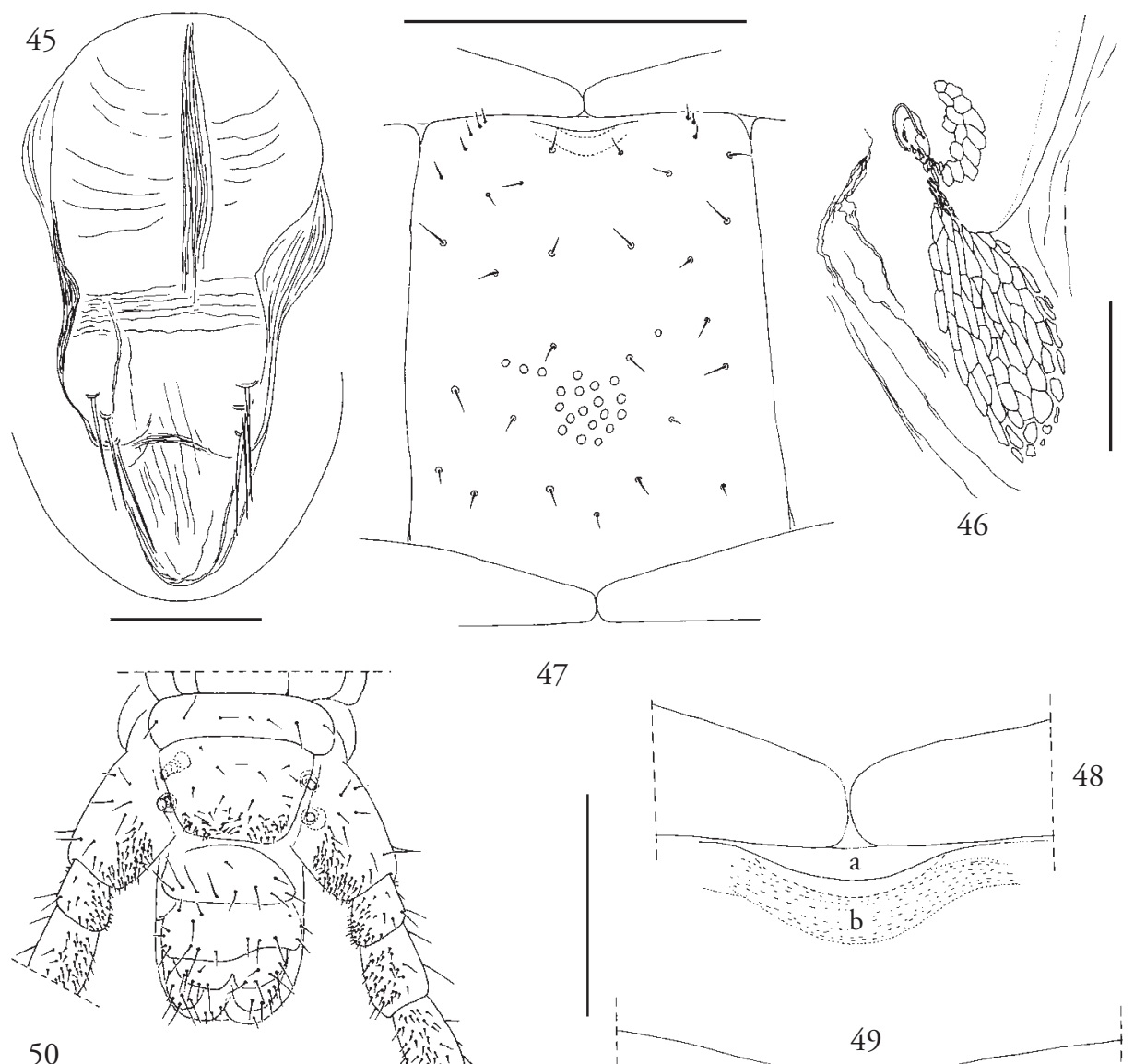

47

50

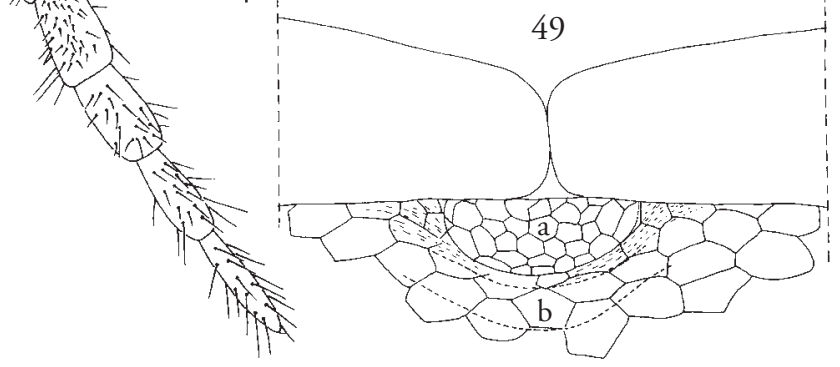

Figures 45-50. (45) Schendylops achalensis sp. n. (ð̋ paratype; Argentina: Córdoba province: Punilla department: Pampa de Achala): penis, dorsal. (46-50) Schendylops demangei (q holotype; Argentina: Chubut province: Biedma department: Puerto Lobos): (46) Detail of postero-external region of left second maxilla, ventral. (47) Sternum V. (48) Detail of middle part of anterior margin of sternum V showing small shallow pit (a: pit, b: internal chitinous thickening). (49) Detail of middle part of anterior margin of sternum IX showing small shallow pit (a: pit, b: internal chitinous thickening). (50) Last leg-bearing segment and terminal segments, ventral. Scale bars: $0.05 \mathrm{~mm}$ (45, 46); $0.2 \mathrm{~mm}$ (47); $0.05 \mathrm{~mm}$ (48, 49); $0.3 \mathrm{~mm}(50)$. 
Type material examined: Holotype: female, 65 leg-bearing segments, body length $29 \mathrm{~mm}$, from Argentina: Chubut province: Biedma department: Puerto Lobos, E. A. Maury leg., 26 January 1975. On a slide. (MLP).

Remarks: The following complementary information can be given on the female holotype: Length of cephalic shield: $0.46 \mathrm{~mm}$; width of forcipular coxosternum: 0.45 $\mathrm{mm}$. Small shallow pits on anterior margin of sterna III-XIII and corresponding internal chitinous thickening, with shape as in Figs 47-49.

Type locality: Argentina: Chubut province: Biedma department: Puerto Lobos.

Known range: Only known from the type locality.

\section{Schendylops demartini (Pereira \& Minelli, 1996)}

Figs 52-58.

Schendylurus demartini Pereira \& Minelli, 1996 - Trop. Zool. 9: 243-246, 292.

Schendylops demartini: Hoffman \& Pereira 1997 - Myriapodologica 5 (2): 21.

Schendylops demartini: Morrone \& Pereira 1999 - Rev. Soc. Entomol. Argent. 58 (3-4): 167, 170.

Schendylops demartini: Foddai, Pereira \& Minelli 2000 - Amazoniana 16: 136, 137.

Diagnosis: The species differs from $S$. achalensis sp. n., S. demangei, S. minutus, and $S$. placcii by the following unique traits (cf. Table 3): 41 leg-bearing segments (male); ratio width of a.a. II/ width of a.a. XIV, 1.85: 1; dorsal side of second article of telopodite of first maxillae with 7 sensilla.

Type material examined: Holotype: male, 41 leg-bearing segments, body length $18 \mathrm{~mm}$, from Argentina: Misiones province: Iguazú department: Puerto Iguazú, De Martin leg., 14-20 October 1982. In alcohol. (MSNVR).
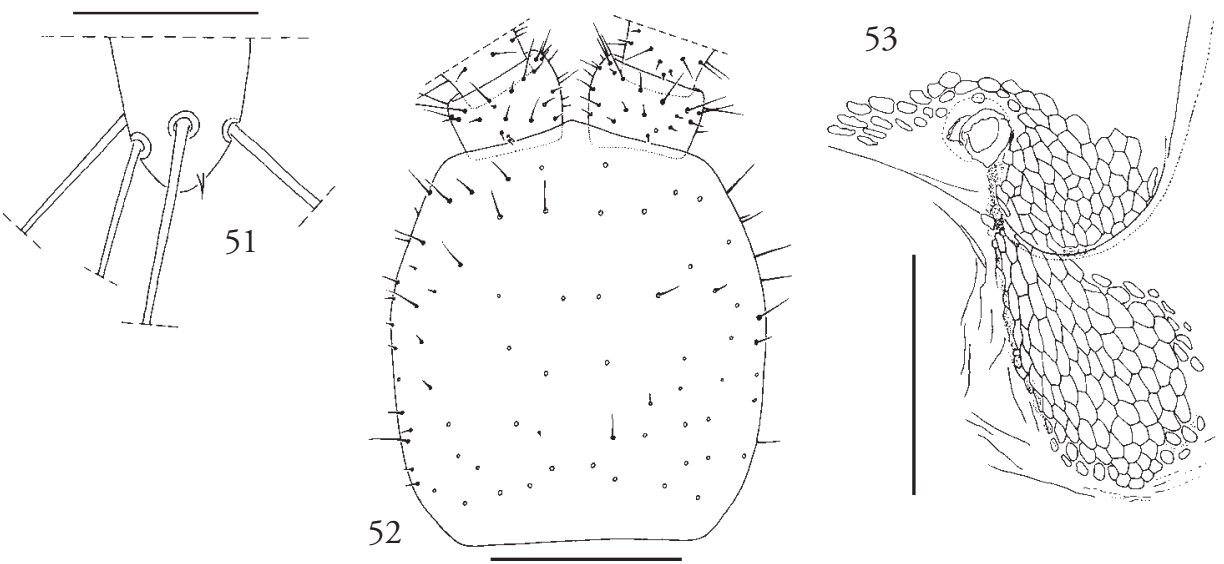

Figures 51-53. (51) Schendylops demangei ( 9 holotype; Argentina: Chubut province: Biedma department: Puerto Lobos): detail of distal end of last podomere of right last leg, dorsal. (52-53) Schendylops demartini (ठ holotype; Argentina: Misiones province: Iguazú department: Puerto Iguazú): (52) Cephalic shield. (53) Detail of postero-external region of left second maxilla, ventral. Scale bars: $0.03 \mathrm{~mm}$ (51); $0.3 \mathrm{~mm}$ (52); $0.1 \mathrm{~mm}$ (53). 


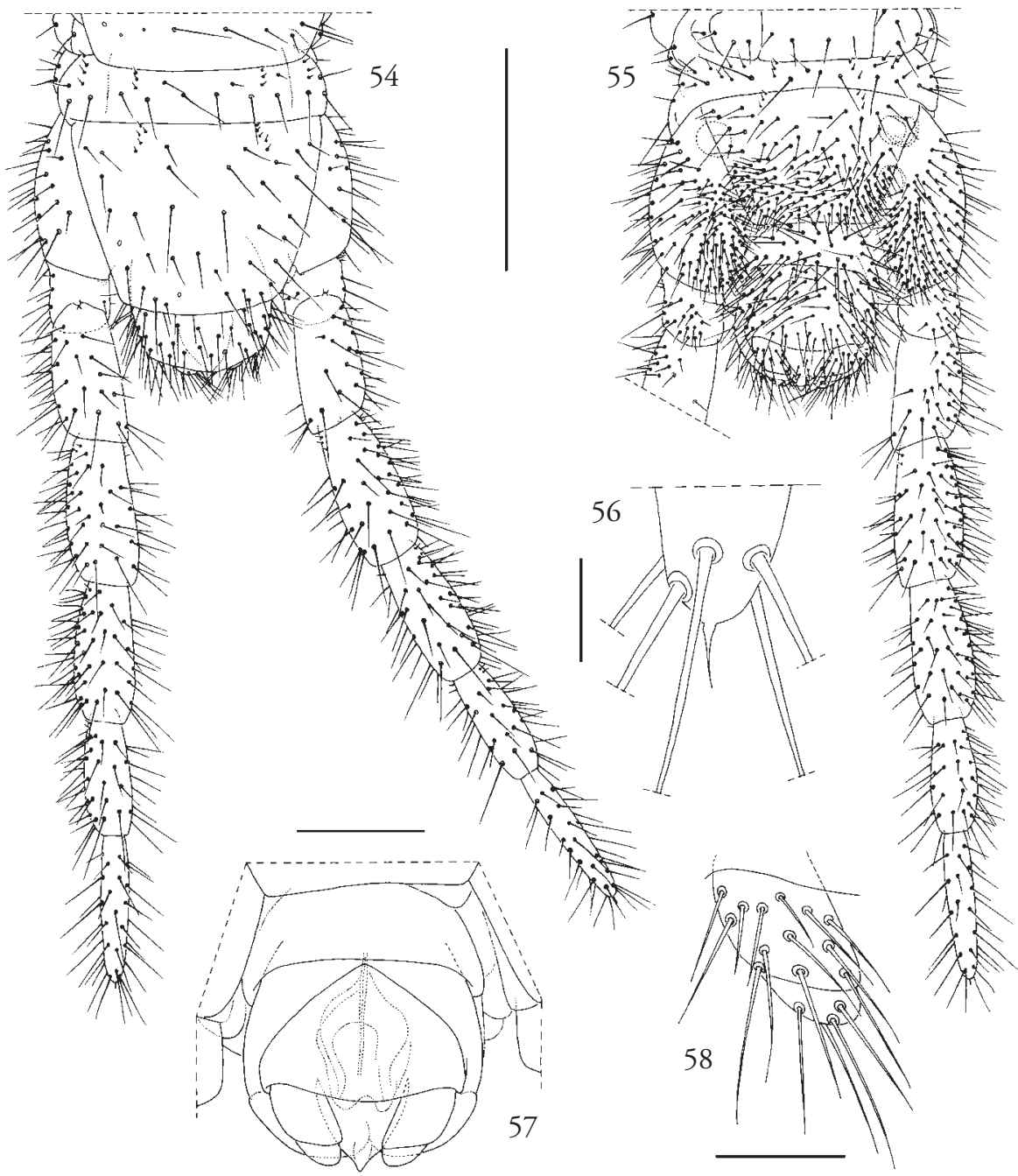

Figures 54-58. Schendylops demartini ( $ठ$ holotype; Argentina: Misiones province: Iguazú department: Puerto Iguazú). (54) Last leg-bearing segment and terminal segments, dorsal. (55) Last leg-bearing segment and terminal segments, ventral. (56) Detail of distal end of last podomere of left last leg, ventral. (57) Terminal segments, ventral. (58) Right gonopod, ventral. Scale bars: $0.3 \mathrm{~mm}$ (54, 55); $0.02 \mathrm{~mm}$ (56); $0.1 \mathrm{~mm}$ (57); $0.05 \mathrm{~mm}$ (58).

Remarks: The following complementary information can be given on the male holotype: specimen with tubula seminifera full of mature spermatozoa; length of cephalic shield $0.60 \mathrm{~mm}$. Forcipular segment: width of coxosternum, $0.64 \mathrm{~mm}$, ratio width/ length of coxosternum, 1.38: 1, ratio length/ width of trochanteroprefemur 1.40:1. Last legs: ratio length of telopodites/ length of last sternum, 5.26: 1, ratio width of tarsus/ width of metatarsus 1.66: 1 .

Type locality: Argentina: Misiones province: Iguazú department: Puerto Iguazú. Known range: Only known from the type locality. 


\section{Schendylops minutus (Pereira \& Minelli, 1993)}

Figs 59-72.

Schendylurus minutus Pereira \& Minelli, 1993 - Trop. Zool., Special Issue 1: 106-108, 121. Schendylops minutus: Hoffman \& Pereira 1997 - Myriapodologica 5 (2): 21. Schendylops minutus: Morrone \& Pereira 1999 - Rev. Soc. Entomol. Argent. 58 (3-4): 167, 170. Schendylops minutus: Foddai, Pereira \& Minelli 2000 - Amazoniana 16: 142.

Diagnosis: The species differs from $S$. achalensis sp. n., S. demangei, S. demartini, and S. placcii by the following unique traits (cf. Table 3): 53 leg-bearing segments (female); body length $11 \mathrm{~mm}$. Antennae: a.a. II-XIII $c a$. as long as wide, type $c$ sensilla absent. Clypeus with six setae on the middle and one praelabral seta. Mandibles: dentate lamellae with 5 teeth, pectinate lamellae with 5 hyaline teeth. First maxillae: lappets of coxosternum small not attaining the anterior margin of first article of the telopodite (Fig. 63), setae of coxosternum absent, second article of telopodites with $1+1$ ventral setae and $2+2$ dorsal sensilla. Second maxillae: coxosternum with 12 setae, apical claw of telopodite with 4 teeth on dorsal and ventral edges. Forcipular segment: length to maximum width ratio of trochanteroprefemur 1.15: 1, length to maximum width ratio of tarsungulum 2.10:1, calyx of poison gland very small, palmate in form (Fig. 67). Single pore fields of anterior and posterior sterna not accompanied at the sides by additional pores. Claws of walking legs curved internally (as shown in Figs 68-70). Ratio width/ length of sternum of last leg-bearing segment 1.33: 1.

Type material examined: Holotype: female, 53 leg-bearing segments, body length $11 \mathrm{~mm}$, from Venezuela: Falcón state: Henri Pittier National Park, Rancho Grande, M. G. Paoletti leg., 16 August 1980. In alcohol. (MLP).

Remarks: Besides the differential characters mentioned in the diagnosis, the following new information can be given on the female holotype: specimen with spermathecae full of spermatozoa placed at level of leg-bearing segments L-LI. Length of cephalic shield: $0.24 \mathrm{~mm}$; width of forcipular coxosternum: $0.23 \mathrm{~mm}$. Antennae: ratio width of a.a. II/ width of a.a. XIV, 1.26: 1; ratio length/ width of a.a. XIV, 2.14: 1; ventral and dorsal surface of a.a. II, V, IX and XIII (Figs 59-60) with very small specialized sensilla; ventral sensilla of two types ( $a$ and $b$ ); type $a$ sensilla very thin and not split apically, type $b$ sensilla very similar to those of the apex of the terminal article (Fig. 59). Position of type $a$ sensilla varies from internal latero-median on a.a. $\mathrm{V}$ to internal latero-apical on a.a. XIII, whereas type $b$ sensilla always occurs on the internal latero-apical region. Dorsal sensilla of two types, $a$ and $b$, similar to $a$ and $b$ of ventral side (Fig. 60). Position of type $a$ sensilla varies from antero-median on a.a. $\mathrm{V}$ to apical-median in a.a. XIII, whereas type $b$ sensilla always occur on the external apical-lateral region of the specified a.a. Distribution of type $a$ and $b$ sensilla as in Table 2. The original description of the species by Pereira and Minelli (1993) only mentions one type of specialized sensilla (here individualized as "type $b$ "). Parungues of walking legs as in Figs 68-70.

Type locality: Venezuela: Falcón state: Henri Pittier National Park, Rancho Grande. Known range: Only known from the type locality. 
Table 2. Number of type $a$ and $b$ sensilla on antennal articles II, V, IX and XIII in the female holotype of Schendylops minutus from Venezuela: Falcón state: Henri Pittier National Park, Rancho Grande.

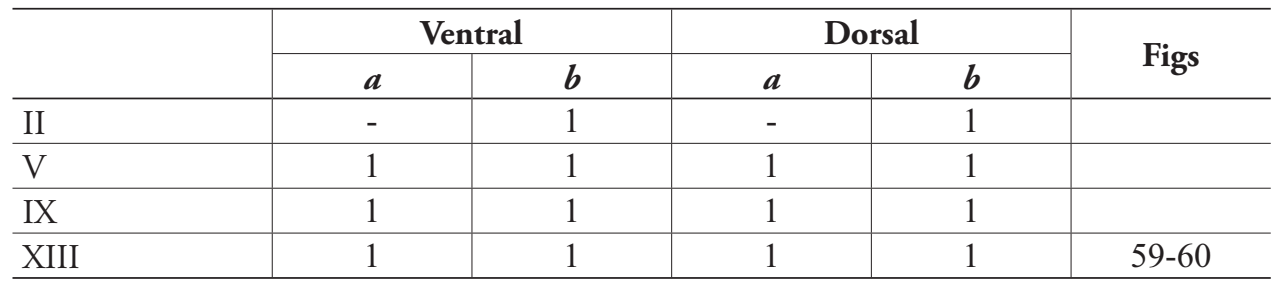
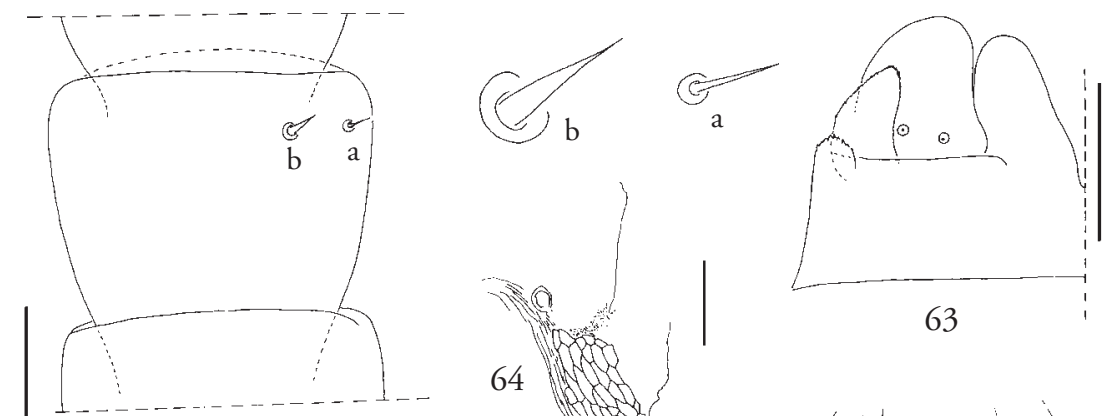

59

64
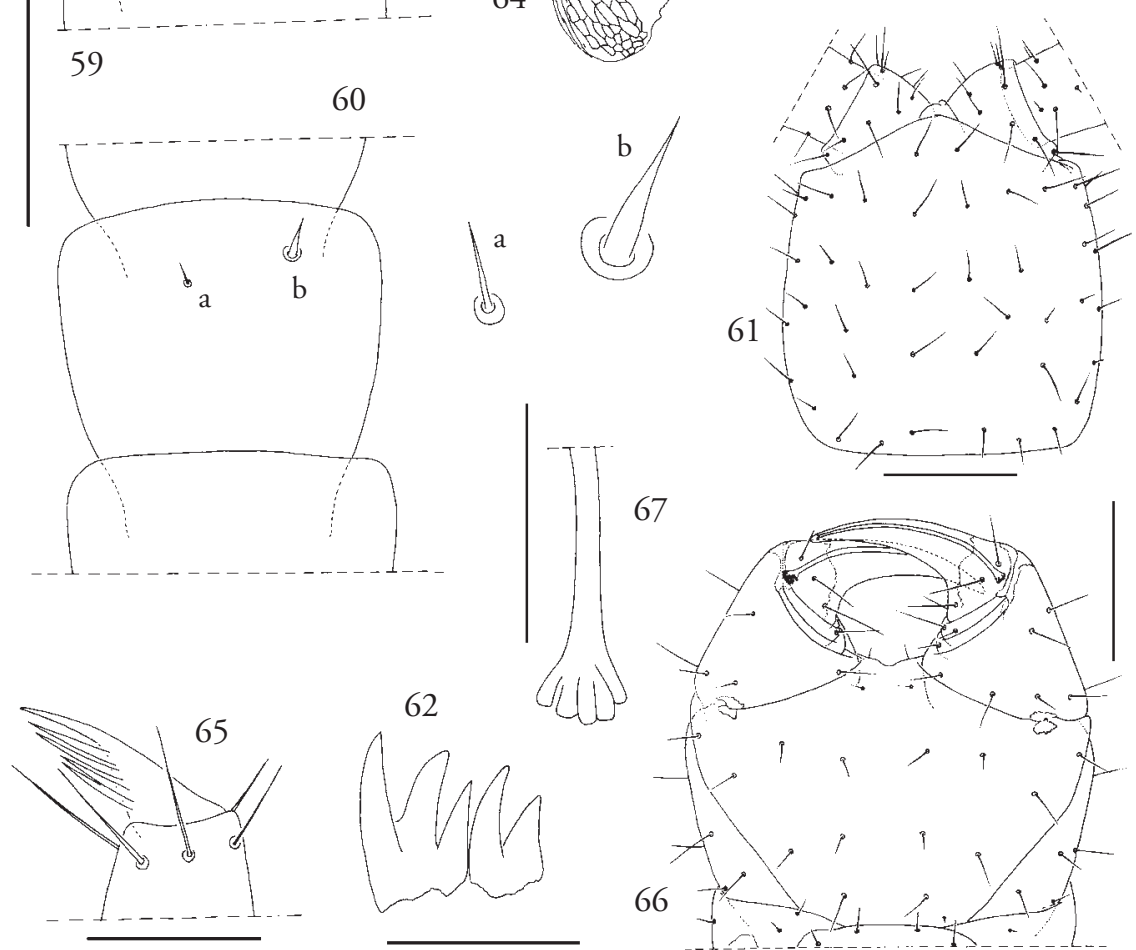

67

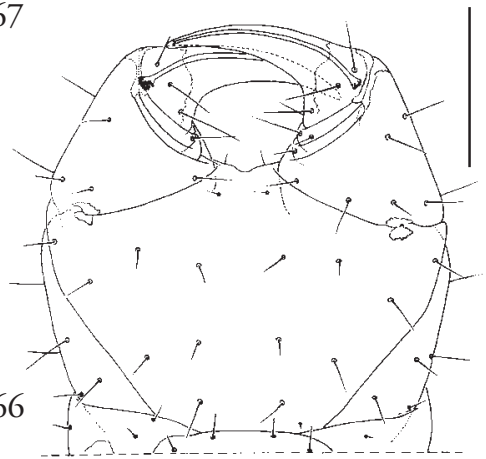

Figures 59-67. Schendylops minutus (ㅇ holotype; Venezuela: Falcón state: Henri Pittier National Park, Rancho Grande). (59) Right a.a. XIII, ventral (a, b: $a, b$ type sensilla). (60) Right a.a. XIII, dorsal (a, b: $a, b$ type sensilla). (61) Cephalic shield and base of antennae. (62) Dentate lamella of right mandible. (63) Left first maxilla, dorsal. (64) Detail of postero-external region of left second maxilla, ventral. (65) Claw of telopodite of right second maxilla, dorsal. (66) Forcipular segment, ventral. (67) Detail of calyx of left poison gland, ventral. Scale bars: 0.05 mm (59, 60); $0.1 \mathrm{~mm}$ (61); $0.01 \mathrm{~mm}$ (62); $0.03 \mathrm{~mm}$ (63, 64); $0.02 \mathrm{~mm}$ (65); $0.1 \mathrm{~mm}$ (66); $0.02 \mathrm{~mm}$ (67). 


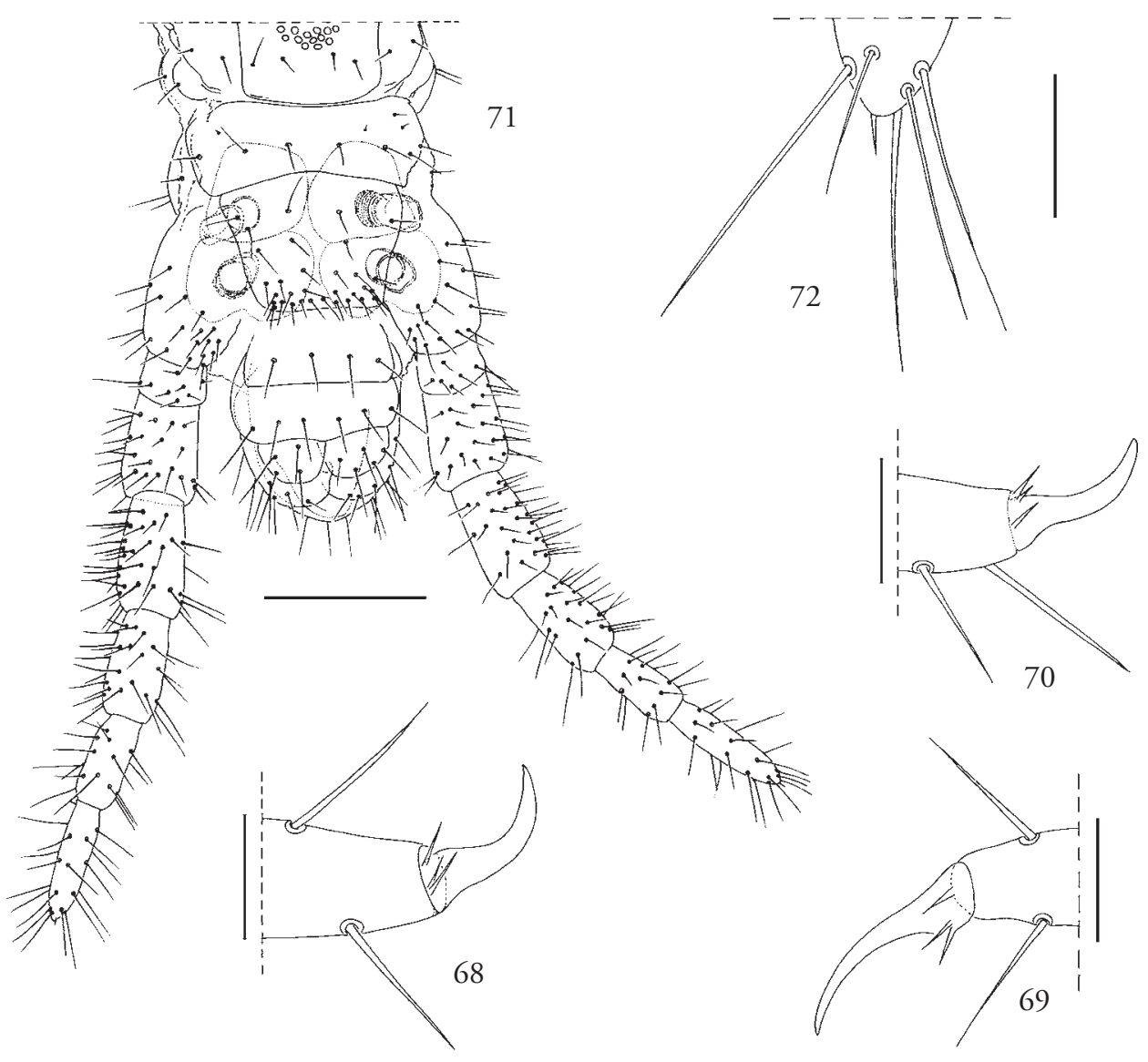

Figures 68-72. Schendylops minutus ( + holotype; Venezuela: Falcón state: Henri Pittier National Park, Rancho Grande). (68) Claw of left leg XXXVIII, postero-ventral view. (69) Claw of right leg XLI, anteroventral view. (70) Claw of left leg LII, antero-ventral view. (71) Last leg-bearing segment and terminal segments, ventral (72) Detail of distal end of last podomere of left last leg, ventral. Scale bars: $0.02 \mathrm{~mm}$ (68-70); $0.1 \mathrm{~mm}$ (71); $0.02 \mathrm{~mm}(72)$.

\section{Schendylops placcii (Pereira \& Minelli, 1996)}

Figs 73-81.

Schendylurus placcii Pereira \& Minelli, 1996 - Trop. Zool. 9: 284-291, 292.

Schendylops placcii: Hoffman \& Pereira 1997 - Myriapodologica 5 (2): 22.

Schendylops placcii: Morrone \& Pereira 1999 - Rev. Soc. Entomol. Argent. 58 (3-4): 167, 171. Schendylops placcii: Foddai, Pereira \& Minelli 2000 - Amazoniana 16: 145.

Diagnosis: The species differs from S. achalensis sp. n., S. demangei, S. demartini, and $S$. minutus by the following unique traits (cf. Table 3): posterior half of lateral margins of head capsule entirely straight and converging posteriad (Fig. 73); dentate 


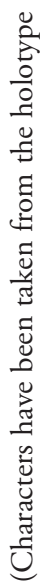

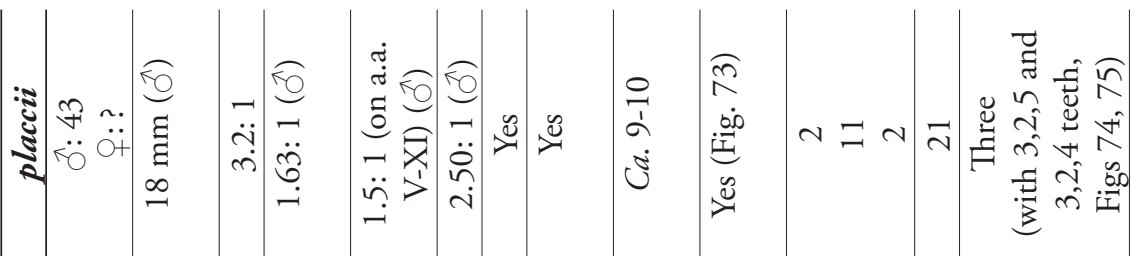

3 导 - Ot

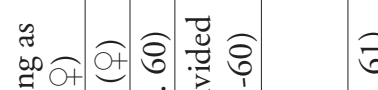

สิ สิ

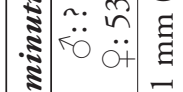

$\begin{array}{lll}\ddot{\sim} & \ddot{\imath} \\ \end{array}$

它

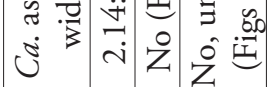

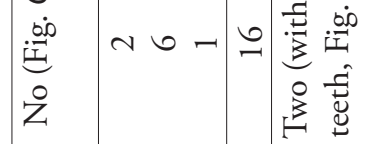

a

:

है

is.

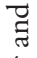

.

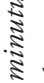

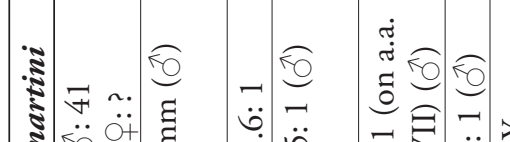

Z

ป

$\infty$

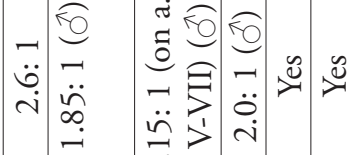

ris

c.

ิำ

空

$\therefore$

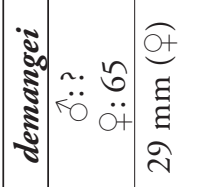

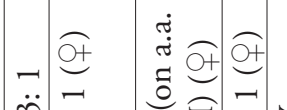

m.

$\ddot{\sim}>\stackrel{\text { N }}{\sim}$

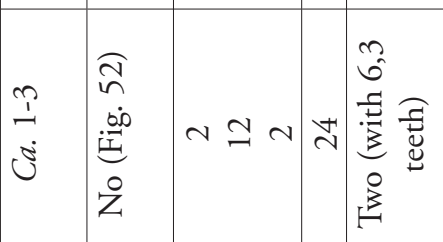

超

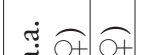

(1)

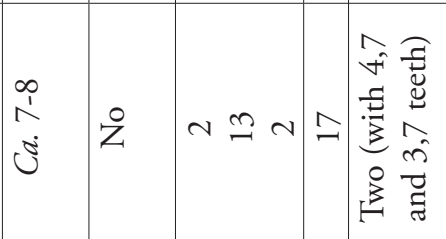

is

के

के

- $\frac{2}{\pi}$

$\frac{2}{8}$ $\ddot{0} \ddot{0}$

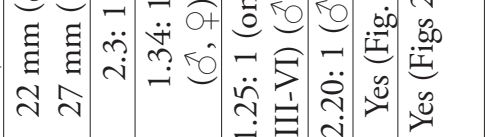

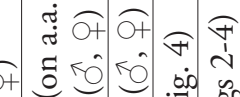

สิ

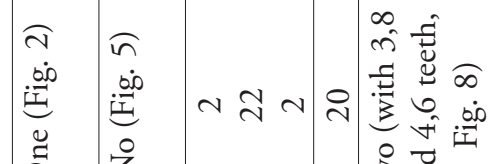

占

들

इ. दे.

है

4

过

प्ष

帘 ำ

롤

离

官

iे

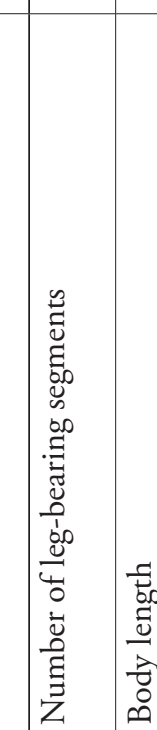

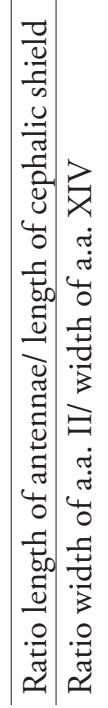

-




\begin{tabular}{|c|c|c|c|c|c|c|c|c|c|c|c|}
\hline 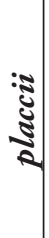 & $\begin{array}{l}\text { ণ } \\
\text { ல் }\end{array}$ & $\stackrel{\substack{+\sim}}{\sim}$ & $\approx$ & $\stackrel{\sim}{\sim}$ & $\begin{array}{l}n \\
\stackrel{f}{n} \\
n\end{array}$ & $\infty$ & 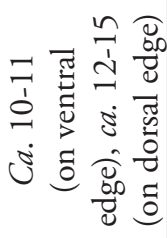 & $\begin{array}{l}0 \\
\therefore \\
.000 \\
i=1 \\
. \Xi \\
2\end{array}$ & 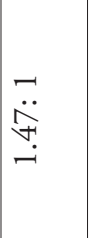 & $\begin{array}{l}\check{n} \\
\stackrel{\sim}{i}\end{array}$ & 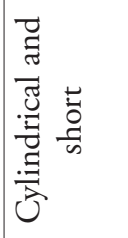 \\
\hline $\begin{array}{r}3 \\
\text { 咅 } \\
3 \\
3 \\
3\end{array}$ & ن & 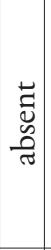 & 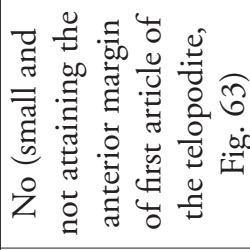 & \pm & $\stackrel{\sim}{+}$ & $\simeq$ & 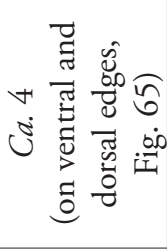 & 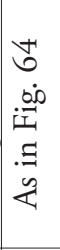 & 茪 & $\begin{array}{c}\ddot{0} \\
\ddot{0} \\
\ddot{i}\end{array}$ & 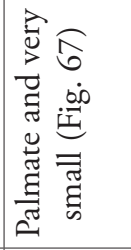 \\
\hline 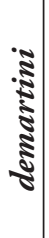 & $\begin{array}{l}\stackrel{0}{ } \\
\text { ல }\end{array}$ & $\stackrel{m}{\stackrel{m}{\sim}}$ & 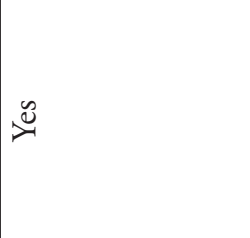 & 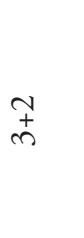 & $\stackrel{+}{+}$ & $\tilde{\sim}$ & 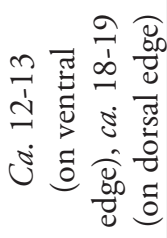 & $\begin{array}{l}n \\
n \\
00 \\
i=1 \\
. \Xi \\
\infty\end{array}$ & 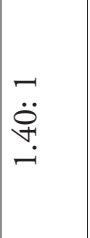 & 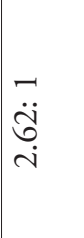 & 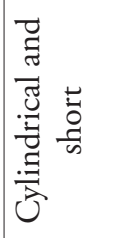 \\
\hline 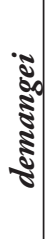 & 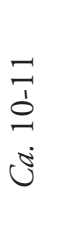 & 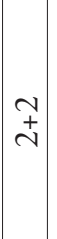 & $\stackrel{\circlearrowright}{\approx}$ & $\stackrel{\sim}{\sim}$ & $\stackrel{+}{+}$ & $\because$ & 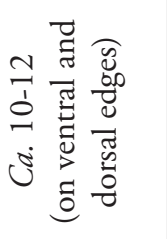 & 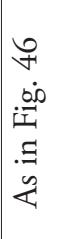 & $\begin{array}{l}\ddot{\sim} \\
\ddot{\sim} \\
\end{array}$ & $\begin{array}{l}\check{0} \\
\tilde{0} \\
\tilde{n}\end{array}$ & 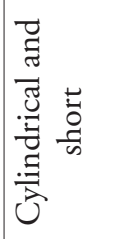 \\
\hline 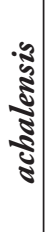 & $\begin{array}{l}\infty \\
\infty \\
0 \\
0 \\
0 \\
0 \\
0\end{array}$ & 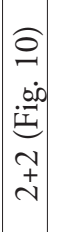 & 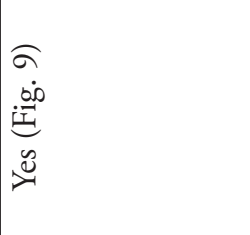 & 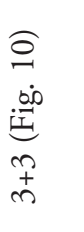 & 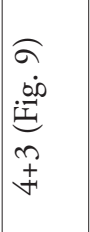 & 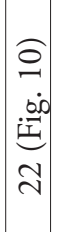 & 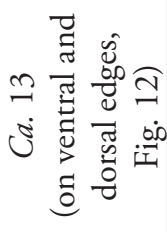 & $\begin{array}{l}7 \\
0 \\
.00 \\
0 \\
. \Xi \\
\infty\end{array}$ & 荅 & 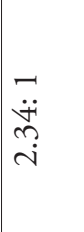 & 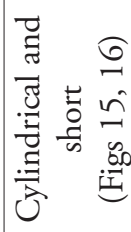 \\
\hline & 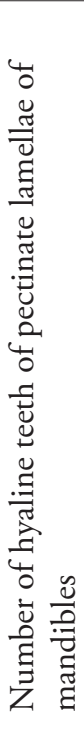 & 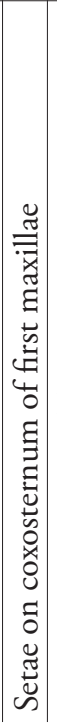 & 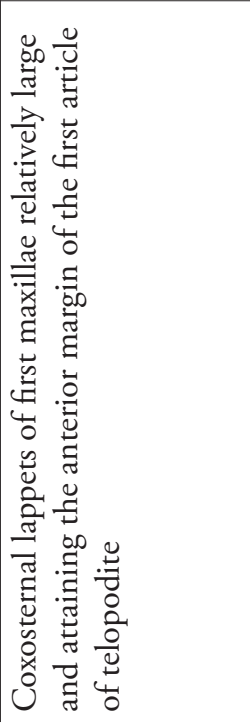 & 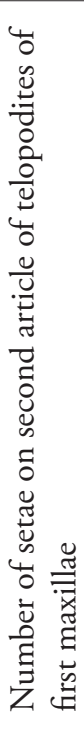 & 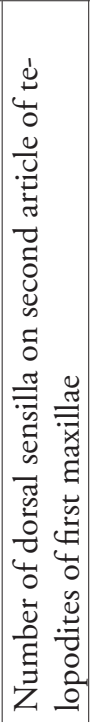 & 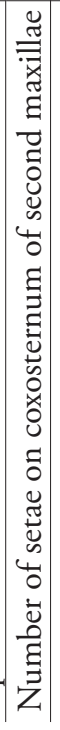 & 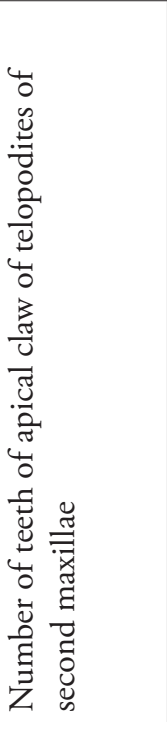 & 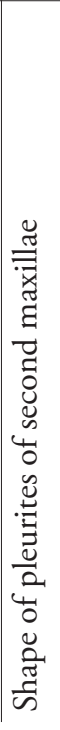 & 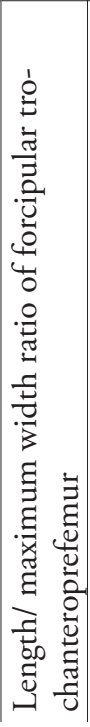 & 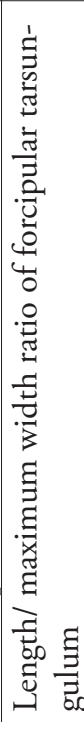 & 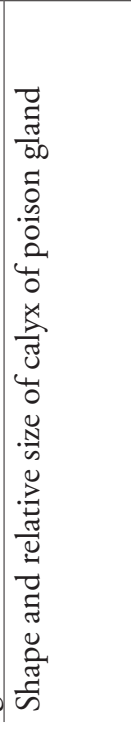 \\
\hline
\end{tabular}




\begin{tabular}{|c|c|c|c|c|c|c|c|c|c|}
\hline $\begin{array}{l}\frac{1}{8} \\
\frac{8}{3}\end{array}$ & $\stackrel{\circ}{Z}$ & 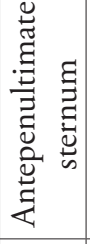 & $\approx$ & 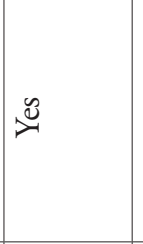 & 之̊ & 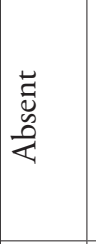 & 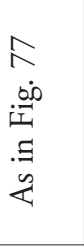 & $n$. & 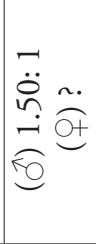 \\
\hline 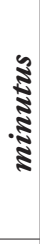 & 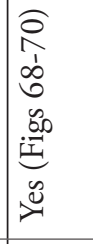 & 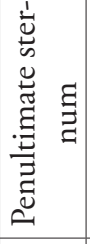 & 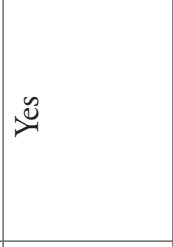 & $\stackrel{\circ}{Z}$ & Z̊ & 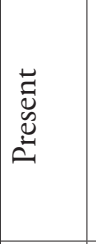 & $\sim$. & $\begin{array}{l}\overline{1} \\
\dot{00} \\
i= \\
. \Xi \\
\dot{1}\end{array}$ & 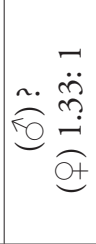 \\
\hline $\begin{array}{l}\text { ปี } \\
\text { ปี } \\
\text { ปี }\end{array}$ & $\stackrel{\circ}{Z}$ & 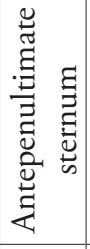 & 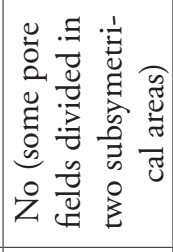 & $\approx$ & Z̊ & 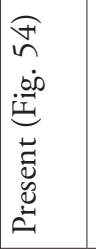 & 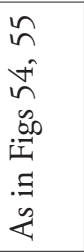 & $\sim$. & 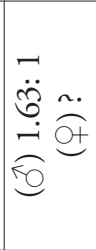 \\
\hline 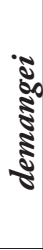 & ' & 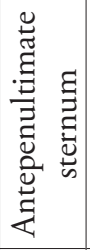 & 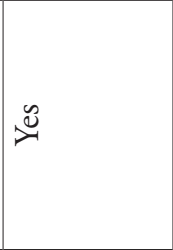 & $\approx$ & 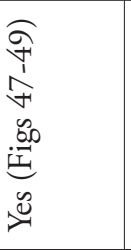 & 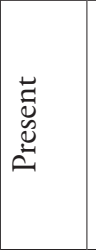 & $n$. & $\begin{array}{l}\stackrel{0}{n} \\
.00 \\
i=1 \\
. \Xi \\
\infty\end{array}$ & 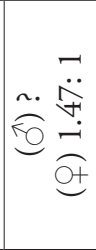 \\
\hline$\frac{3}{\frac{3}{3}} \frac{3}{3}$ & 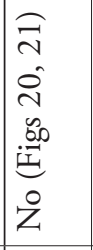 & 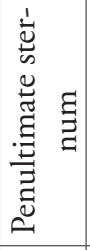 & 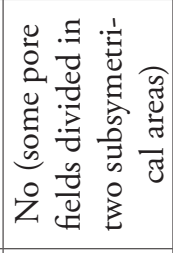 & 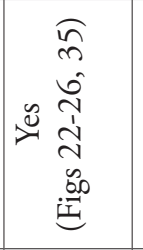 & 之o & 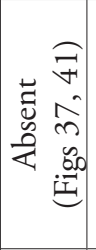 & 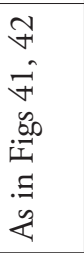 & 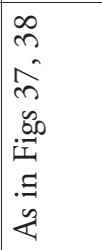 & 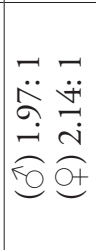 \\
\hline & 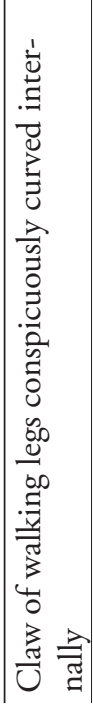 & 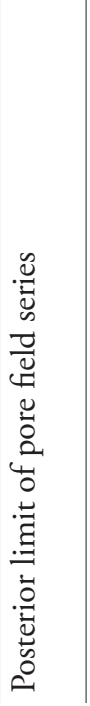 & 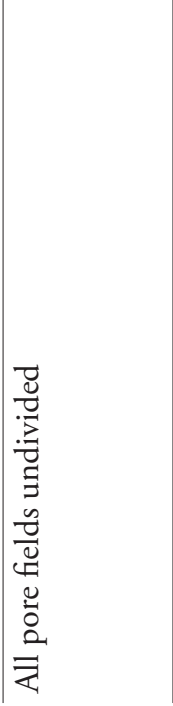 & 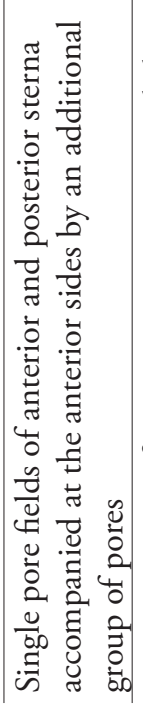 & 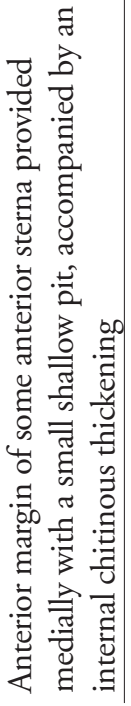 & 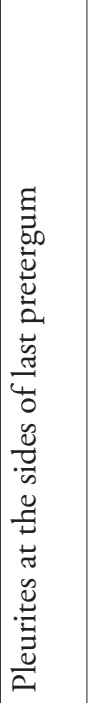 & 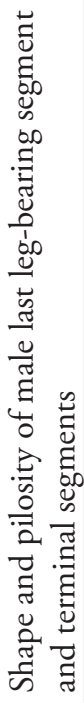 & 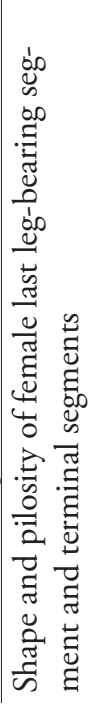 & 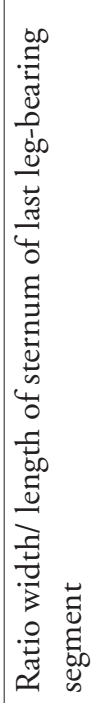 \\
\hline
\end{tabular}




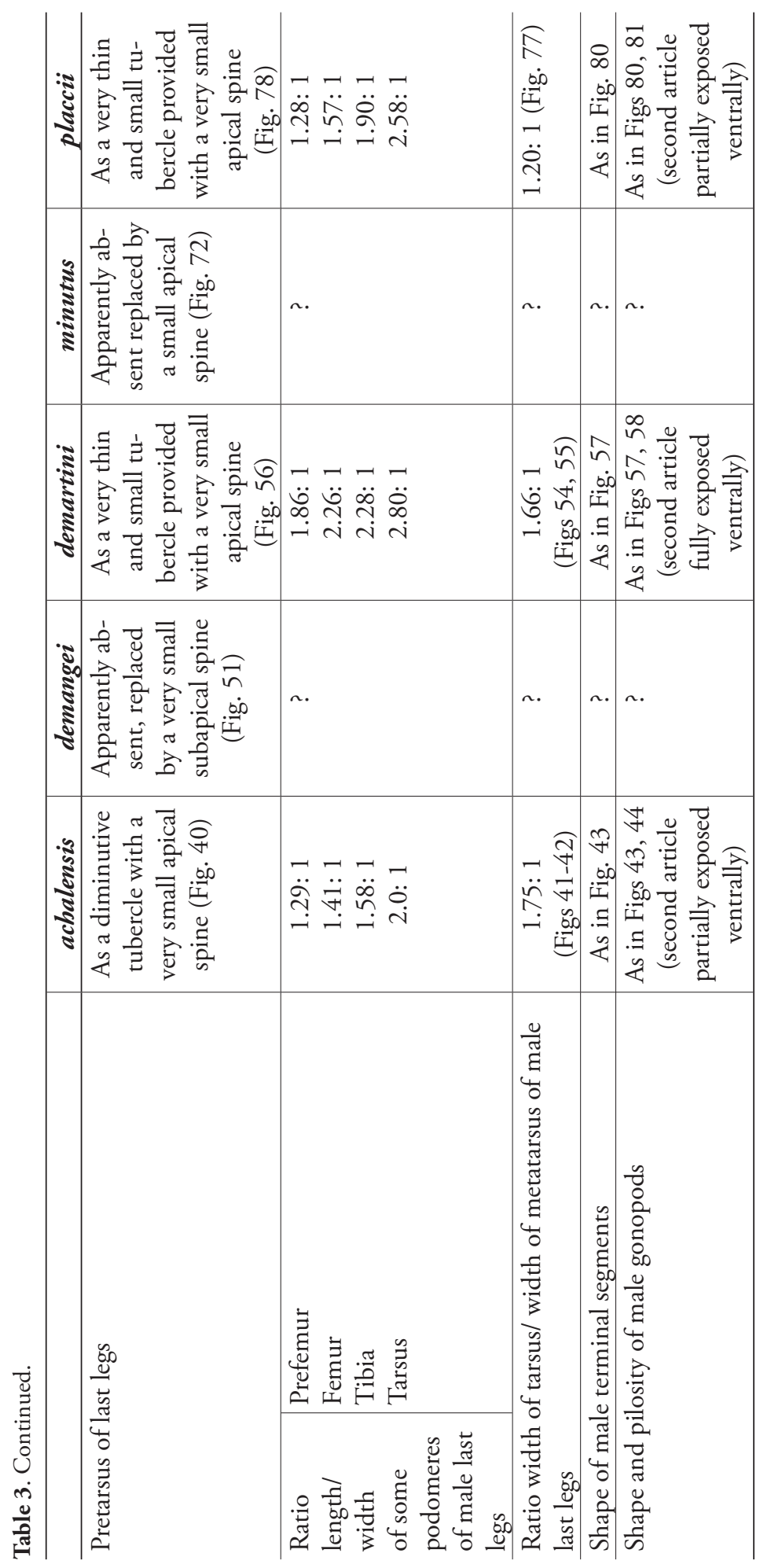



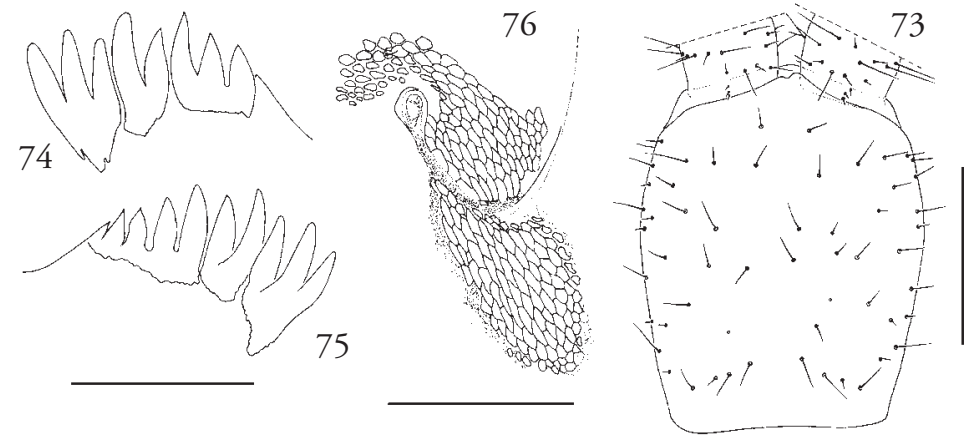

Figures 73-76. Schendylops placcii ( $\widehat{\jmath}$ holotype; Argentina: Formosa province: Formosa department: Río Pilagá). (73) Cephalic shield and base of antennae. (74) Dentate lamella of left mandible. (75) Dentate lamella of right mandible. (76) Detail of postero-external region of left second maxilla, ventral. Scale bars: $0.3 \mathrm{~mm}$ (73); $0.03 \mathrm{~mm}(74,75) ; 0.1 \mathrm{~mm}(76)$.

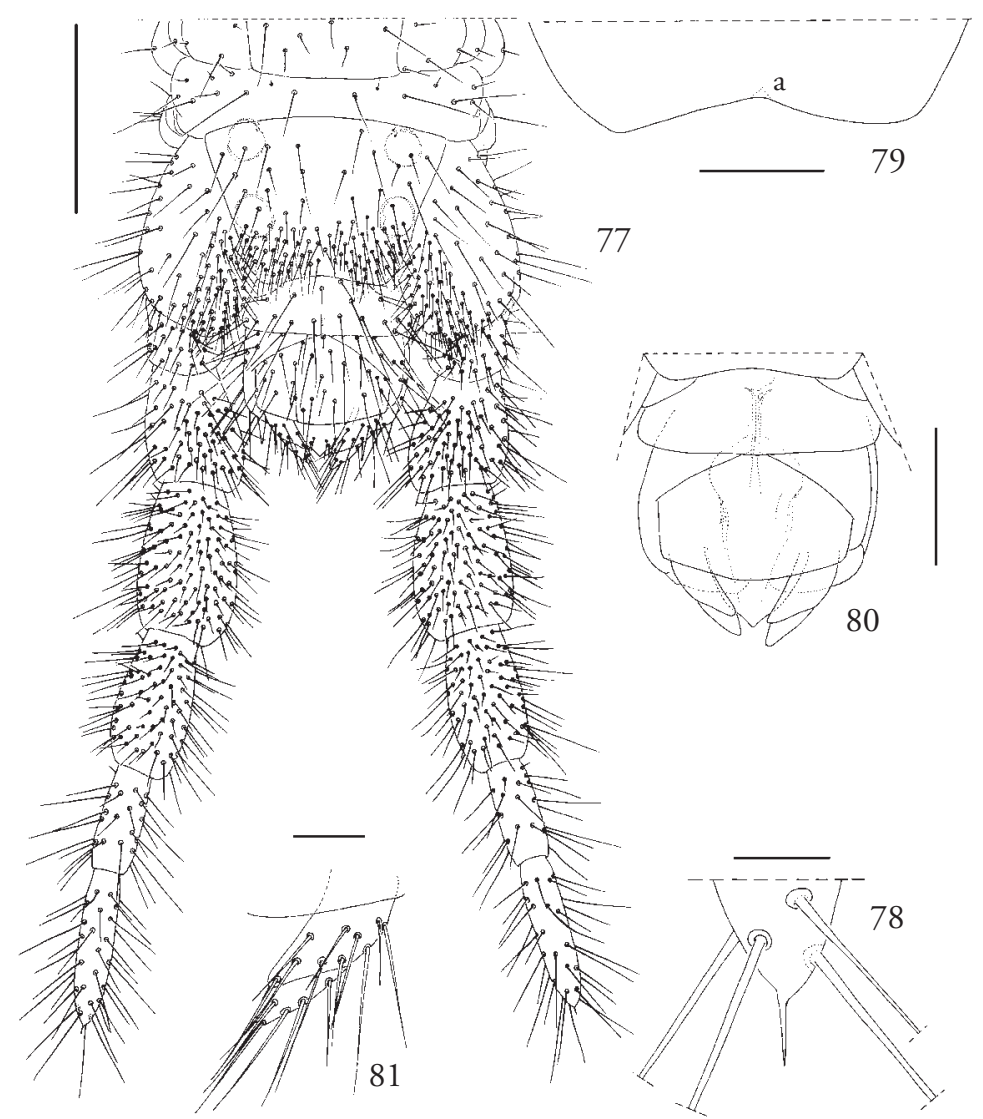

Figures 77-81. Schendylops placcii ( $\widehat{\jmath}$ holotype; Argentina: Formosa province: Formosa department: Río Pilagá). (77) Last leg-bearing segment and terminal segments, ventral. (78) Detail of distal end of last podomere of right last leg, ventral. (79) Detail of posterior margin of the sternum of last leg-bearing segment (a: small dorsal notch). (80) Terminal segments, ventral. (81) Left gonopod, ventral. Scale bars: $0.2 \mathrm{~mm}$ (77); $0.02 \mathrm{~mm}$ (78); $0.05 \mathrm{~mm}$ (79); $0.1 \mathrm{~mm}$ (80); $0.03 \mathrm{~mm}$ (81). 
lamellae of mandibles divided into three blocks (Figs 74, 75); length/ width ratio of a.a. XIV, 2.50: 1 .

Remarks: the following new information can be given on the male holotype: specimen with tubula seminifera full of mature spermatozoa; length of cephalic shield: 0.57 $\mathrm{mm}$; width of forcipular coxosternum: $0.50 \mathrm{~mm}$.

Type material examined: Holotype: male, 43 leg-bearing segments, body length $18 \mathrm{~mm}$, from Argentina: Formosa province: Formosa department: Río Pilagá

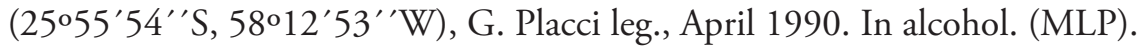

Type locality: Argentina: Formosa province: Formosa department: Río Pilagá.

Known range: Only known from the type locality.

\section{Acknowledgments}

I am indebted to Martin J. Ramirez and Lara Lopardo (Museo Argentino de Ciencias Naturales "Bernardino Rivadavia", Buenos Aires) for collecting the specimens of the new species herein described and to Cristina Scioscia, curator of Arachnida and Myriapoda, of the same Museum for the loan of this interesting material. William Shear (Hampden-Sydney College, Virginia) provided valuable suggestions and linguistic help on the final draft of the manuscript. The paper was improved also by useful comments from Pavel Stoev (National Museum of Natural History, Sofia) and an anonymous referee. Hernán L. Pereira (La Plata) edited the digitalized figures.

\section{References}

Brölemann, H.W. \& Ribaut, H. (1912) Essai d'une monographie des Schendylina (Myriapodes, Géophilomorphes). - Nouvelles Archives du Muséum d'Histoire Naturelle, Paris sér. 5, 4: 53-183.

Demange, J.-M. \& Pereira, L. A (1979) Deux anomalies segmentaires chez deux espèces de Géophilomorphes du Pérou (Myriapoda: Chilopoda). - Senckenbergiana biologica, Frankfurt 60 (3/4): 261-267.

Demange, J.-M. \& Pereira, L. A. (1985) Géophilomorphes (Myriapoda, Chilopoda) de la Guadeloupe et ses Dépendances. - Bulletin du Muséum national d'Histoire naturelle, Paris, 4 sér., section A, n. 1: 181-199.

Foddai, D., Minelli, A. \& Pereira, L. A. (2002) Chilopoda Geophilomorpha. - In: Adis, J. (ed.) Amazonian Arachnida \& Myriapoda. Pensoft Publ., Sofia Moscow, p. 459-474.

Foddai, D., Pereira, L. A. \& Minelli, A. (2000) A catalogue of the geophilomorph centipedes (Chilopoda) from Central and South America including Mexico. - Amazoniana 16: 59-185.

Hoffman, R. L. \& Pereira, L. A. (1997) The identity and taxonomic status of the generic names Schendylops Cook, 1899, and Schendylurus Silvestri, 1907, and the proposal of Orygmadyla, a new related genus from Peru (Chilopoda: Geophilomorpha: Schendylidae). - Myriapodologica 5 (2): 9-32. 
Jofré, G., Reading, C. \& Di Tada, I. (2007) Habitat selection in the Pampa de Achala toad, Bufo achalensis. - Amphibia-Reptilia 28: 129-138.

Minelli, A. (Ed.) (2006). ChiloBase: A World Catalogue of Centipedes (Chilopoda) for the Web. Available from http://chilobase.bio.unipd.it (accessed 1 March 2007).

Morrone, J. J. \& Pereira, L. A. (1999) On the geographical distribution of the Neotropical and Andean species of Schendylops (Chilopoda: Geophilomorpha: Schendylidae). - Revista de la Sociedad Entomológica Argentina 58 (3-4): 165-171.

Pereira, L. A. (1981) Estudios sobre Geofilomorfos neotropicales IV. Sobre cuatro especies nuevas del género Schendylurus Silvestri, 1907 (Chilopoda: Geophilomorpha: Schendylidae). - Revista de la Sociedad Entomológica Argentina 40 (1-4): 115-138.

Pereira, L. A. (1983 a) Estudios sobre Geofilomorfos neotropicales V. Sobre algunas especies de Schendylidae referidas por Silvestri al género Nannophilus (Chilopoda: Geophilomorpha). - Bolletino del Laboratorio di Entomologia agraria Filippo Silvestri, Portici 40: 69-87.

Pereira, L. A. (1983 b) Estudios sobre Geofilomorfos neotropicales VI. A cerca de la verdadera identidad de "Geophilus sublaevis Meinert, 1870" (Chilopoda: Geophilomorpha: Schendylidae). - Neotrópica 29 (83): 183-188.

Pereira, L. A. (1983 c) Estudios sobre Geofilomorfos neotropicales VII. Sobre algunas especies andinas del género Schendylurus Silvestri, 1907 (Chilopoda: Geophilomorpha: Schendylidae). - Revista de la Sociedad Entomológica Argentina 42 (1-4): 55-74.

Pereira, L. A. (1984) Estudios sobre Geofilomorfos neotropicales VIII. Sobre una nueva especie perteneciente al género Schendylurus Silvestri, 1907 (Chilopoda: Geophilomorpha: Schendylidae). - Neotrópica 30 (83): 63-74.

Pereira, L. A. (1985 a) Estudios sobre Geofilomorfos neotropicales XI. Sobre algunas especies andinas del género Schendylurus Silvestri, 1907, descriptas por R. V. Chamberlin en 1956 y 1957 (Chilopoda: Geophilomorpha: Schendylidae). - Bolletino del Laboratorio di Entomologia agraria Filippo Silvestri, Portici 42: 47-80.

Pereira, L. A. (1985 b) Estudios sobre Geofilomorfos neotropicales XII. Nuevos aportes al conocimiento de Schendylurus perditus Chamberlin, 1914 y Schendylurus varipictus (Chamberlin, 1950) (Chilopoda: Geophilomorpha: Schendylidae). - Revista de la Sociedad Entomológica Argentina 44 (1): 17-30.

Pereira, L. A. (1998) Chilopoda. - In: Morrone, J. J. \& Coscarón, S. (eds.) Biodiversidad de Artrópodos Argentinos. Una perspectiva biotaxonómica. Ediciones Sur, La Plata, p. 463-474.

Pereira, L. A. (1999) Un nouveau cas de dimorphisme sexuel chez les Schendylidae: Schendylops virgingordae (Crabill, 1960), espèce halophile nouvelle pour la Martinique (Myriapoda, Chilopoda, Geophilomorpha). - Zoosystema 21 (3): 525-533.

Pereira, L. A. (2000) The preparation of centipedes for microscopical examination with particular reference to the Geophilomorpha. - Bulletin of the British Myriapod Group 16: 22-25. Pereira, L. A., Foddai, D. \& Minelli, A. (1997) Zoogeographical aspects of Neotropical Geophilomorpha (Chilopoda). - Entomologica scandinavica Supplement 51: 77-86.

Pereira, L. A., Foddai, D. \& Minelli, A. (2002) A new Brazilian Schendylid centipede (Chilopoda: Geophilomorpha) with unusually structured antennae. - Zoologischer Anzeiger 241: 57-65.

Pereira, L. A. \& Minelli, A. (1993) On two new species of Schendylurus Silvestri 1907 from Venezuela, with redescription of S. colombianus Chamberlin 1921 and S. virgingordae Cra- 
bill 1960 (Chilopoda Geophilomorpha Schendylidae). - Tropical Zoology, Special Issue 1: 105-123.

Pereira, L. A. \& Minelli, A. (1994) The African species of the genus Schendylurus Silvestri, 1907 (Chilopoda: Geophilomorpha: Schendylidae). - Bolletino della Società entomologica italiana, Genova 73: 29-58.

Pereira, L. A. \& Minelli, A. (1996) The species of the genus Schendylurus Silvestri 1907 of Argentina, Brazil and Paraguay (Chilopoda Geophilomorpha Schendylidae). - Tropical Zoology 9: 225-295.

Pereira, L. A. \& Minelli, A. (2001) A redescription of the South African centipede Schendylops caledonicus (Attems, 1928) (Chilopoda Geophilomorpha Schendylidae). - Bolletino della Società entomologica italiana 133 (1): 13-25.

Pereira, L. A., Minelli, A. \& Barbieri, F. (1994) New and little known geophilomorph centipedes from Amazonian inundation forests near Manaus, Brazil (Chilopoda: Geophilomorpha). - Amazoniana 13 (1-2): 163-204.

Pereira, L. A., Minelli, A. \& Barbieri, F. (1995) Description of nine new centipede species from Amazonia and related matters on Neotropical Geophilomorphs (Chilopoda: Geophilomorpha). - Amazoniana 13 (3-4): 325-416.

Pereira, L. A., Minelli, A. \& Uliana, M. (2004) The species of Schendylops Cook, 1899 (Chilopoda, Geophilomorpha, Schendylidae) from Madagascar. - Zoosystema 26 (4): 727-752.

Roig Juñent, S., Flores, G. E. \& Mattoni, C. (2003) Consideraciones biogeográficas de la Precordillera (Argentina) basadas en artrópodos epígeos. - In: Morrone, J. J. \& LlorenteBousquets, J. (eds.) Una perspectiva latinoamericana de la Biogeografía. Las Prensas de Ciencias, Facultad de Ciencias, Universidad Nacional Autónoma de México, México, Distrito Federal, p. 275-288.

Roig Juñent, S., Debandi, G. (2004) Prioridades de conservación aplicando información filogenética y endemicidad: un ejemplo basado en Carabidae (Coleoptera) de América del Sur austral. - Revista Chilena de Historia Natural 77: 695-709. 